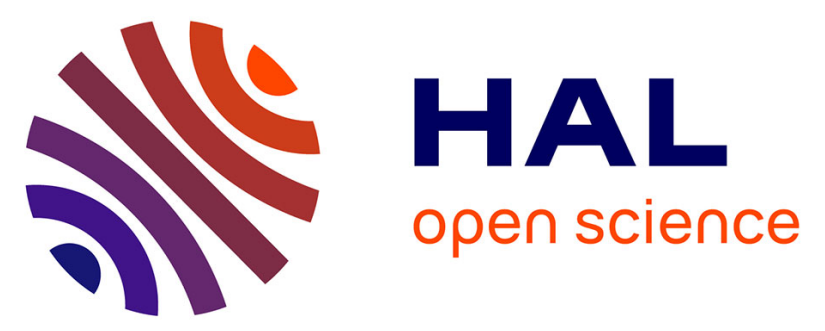

\title{
Geophysical and geomorphological investigations of a Quaternary karstic paleolake and its underground marine connection in Cassis (Bestouan, Cassis, SE France)
}

\author{
Carole Romey, Pierre Rochette, Claude Vella, Bruno Arfib, Valérie \\ Andrieu-Ponel, Regis Braucher, Cedric Champollion, Marc Douchet, Philippe \\ Dussouillez, Daniel Hermitte, et al.
}

\section{- To cite this version:}

Carole Romey, Pierre Rochette, Claude Vella, Bruno Arfib, Valérie Andrieu-Ponel, et al.. Geophysical and geomorphological investigations of a Quaternary karstic paleolake and its underground marine connection in Cassis (Bestouan, Cassis, SE France). Geomorphology, 2014, 214, pp.402-415. 10.1016/j.geomorph.2014.02.021 . hal-02883872

\section{HAL Id: hal-02883872 \\ https://hal.umontpellier.fr/hal-02883872}

Submitted on 29 Jun 2020

HAL is a multi-disciplinary open access archive for the deposit and dissemination of scientific research documents, whether they are published or not. The documents may come from teaching and research institutions in France or abroad, or from public or private research centers.
L'archive ouverte pluridisciplinaire HAL, est destinée au dépôt et à la diffusion de documents scientifiques de niveau recherche, publiés ou non, émanant des établissements d'enseignement et de recherche français ou étrangers, des laboratoires publics ou privés. 


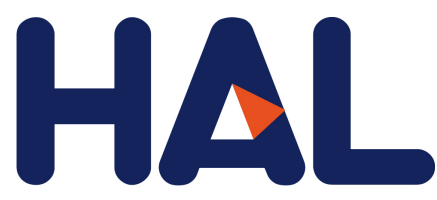

archives-ouvertes

\title{
Geophysical and geomorphological investigations of a Quaternary karstic paleolake and its underground marine connection in Cassis (Bestouan, Cassis, SE France)
}

\author{
Carole Romey, Pierre Rochette, Claude Vella, Bruno Arfib, Valérie \\ Andrieu-Ponel, Regis Braucher, Cedric Champollion, Marc Douchet, Philippe \\ Dussouillez, Daniel Hermitte, et al.
}

\section{- To cite this version:}

Carole Romey, Pierre Rochette, Claude Vella, Bruno Arfib, Valérie Andrieu-Ponel, et al.. Geophysical and geomorphological investigations of a Quaternary karstic paleolake and its underground marine connection in Cassis (Bestouan, Cassis, SE France). Geomorphology, Elsevier, 2014, 214, pp.402-415. 10.1016/j.geomorph.2014.02.021 . hal-02883872

\section{HAL Id: hal-02883872 \\ https://hal.umontpellier.fr/hal-02883872}

Submitted on 29 Jun 2020

HAL is a multi-disciplinary open access archive for the deposit and dissemination of scientific research documents, whether they are published or not. The documents may come from teaching and research institutions in France or abroad, or from public or private research centers.
L'archive ouverte pluridisciplinaire HAL, est destinée au dépôt et à la diffusion de documents scientifiques de niveau recherche, publiés ou non, émanant des établissements d'enseignement et de recherche français ou étrangers, des laboratoires publics ou privés. 


\title{
Geophysical and geomorphological investigations of a Quaternary karstic paleolake and its underground marine connection in Cassis (Bestouan, Cassis, SE France)
}

\author{
Carole Romey $^{\mathrm{a}, *}$, Pierre Rochette ${ }^{\mathrm{a}}$, Claude Vella ${ }^{\mathrm{a}}$, Bruno Arfib ${ }^{\mathrm{a}}$, Valérie Andrieu-Ponel ${ }^{\mathrm{b}}$, Régis Braucher ${ }^{\mathrm{a}}$, \\ Cédric Champollion ${ }^{\mathrm{c}}$, Marc Douchet ${ }^{\mathrm{d}}$, Philippe Dussouillez ${ }^{\mathrm{a}}$, Daniel Hermitte ${ }^{\mathrm{a}}$, Emanuela Mattioli ${ }^{\mathrm{e}}$, \\ Jean-Claude Parisot ${ }^{\mathrm{a}}$, Jean-Luc Schwenninger ${ }^{\mathrm{f}}$ \\ a Aix-Marseille Université, CNRS, CEREGE, Eurôpole de l'Arbois BP80, 13545 Aix-en-Provence Cedex4, France \\ b Aix-Marseille Université, CNRS, IMBE, Eurôpole de l'Arbois BP80, 13545 Aix-en-Provence Cedex4, France \\ c Université Montpellier II, Laboratoire de Géosciences, Place Bataillon, 34095 Montpellier Cedex5, France \\ ' Association Cassis La Rivière Mystérieuse, M.E.V.A., 4 rue Séverin Icard, 13260 Cassis, France \\ e UMR 5276 CNRS LGLTPE, Université Lyon 1, ENS Lyon, bâtiment Géode 2 rue Raphaël Dubois, 69622 Villeurbanne Cedex, France \\ ${ }^{\mathrm{f}}$ University of Oxford, Research Laboratory for Archaeology and the History of Art, Dyson Perrins Building, South Parks Road, OX1 3QY Oxford, United Kingdom
}

\section{A R T I C L E I N F O}

\section{Article history:}

Received 22 May 2013

Received in revised form 13 February 2014

Accepted 16 February 2014

Available online 3 March 2014

\section{Keywords:}

Karst

Provence

Geophysical prospection

Submarine spring

Paleolake

Cassis

Bestouan

\begin{abstract}
A B S T R A C T
An original karstic system in a coastal alluvial plain located in a carbonate environment (Cassis, Provence - SE France) was studied using a multi-method approach (electrical resistivity tomography, gravimetric, passive seismic survey), combined with geomorphologic methods, surface observations and drilling. Limestone dissolution and/or cavity collapse led to the development of a polje, which was filled rapidly by erosion of Aptian marls. The combination of several dating and paleoenvironmental proxies indicates that the polje was filled during a glacial period (MIS 6, 8 or 10, i.e. in the 130-360 ka age range). This discovery has implications for the understanding of karst processes. The connection between the polje and the three km-long Bestouan underwater karstic conduit with submarine outlet is strongly suggested by sedimentological studies and geophysical prospections.
\end{abstract}

\section{Introduction}

Karst areas, which represent about $20 \%$ of the land surface, are characterised by a specific landscape, usually devoid of surface runoff but with surface (e.g. sinkhole, canyons) or deep (e.g. caves, underground rivers) karstic structures (Ford and Williams, 2007; de Waele et al., 2009). Karst structures present major economic and societal challenges (e.g. Margiotta et al., 2012). They are adequate for agriculture and ideal sites for human habitation (Siart et al., 2010). However, karst systems have very heterogeneous landforms and it is very difficult to study the extent and geometry of deep structures. Understanding the link between the endokarst and exokarst features and their 3D geometry (Audra and Palmer, 2013) is of particular interest for fresh groundwater management and for geotechnical issues. Karstic sediments are also used for paleoenvironmental studies as they function as terrestrial archives (Delannoy et al., 2009). Water flow is responsible

\footnotetext{
* Corresponding author. Tel.: + 33442971581

E-mail address: romey@cerege.fr (C. Romey).
}

for karst development in surface landscapes and underground carbonate rocks where dissolution open voids. Surface water can also sink below ground, forming an underground river flowing through large karstic conduits (Mocochain et al., 2009).

Poljes are karstic structures in the form of a large and flat-floored enclosed depression. The flat floor is caused by flooding during high flows due to inefficiency of underground drainage. Ford and Williams (2007) recognized three types of polje according to their main function: (1) poljes dominated by allogenic input controls are very common along highlands that can supply abundant clastic load to rivers; (2) structural poljes are dominated by bedrock geological controls; and (3) base-level poljes are dominated by water-table control.

The Mediterranean region is very suitable for the study of karstic phenomena due to ubiquitous limestone lithology, mainly of Cretaceous but also of Jurassic age (Audra et al., 2004), in particular in SE France. Limestones in Provence are often massive and deformed by a complex tectonic history (Demory et al., 2011; Molliex et al., 2011; Lamarche et al., 2012), with significant relief-related energy that is important for karst formation. Karstic areas are shaped by eustatic and/or tectonic forcing as well as hydrological changes. Coastal karst refers to karstic 
features which have been repeatedly flooded and drained by oscillating sea levels. The evolution of coastal carbonate karst depends on many factors such as groundwater hydrodynamic behaviour which is linked to sea-level changes (van Hengstum et al., 2011; Canora et al., 2012). Sea level has a key role in the formation and functioning of coastal karst structures around Mediterranean Sea: 1) the draw-down of sea level during the Messinian Salinity Crisis is responsible for the development of karst networks below glacial period sea level (Audra et al., $2004) ; 2$ ) the rise of sea level during the Holocene caused the development and flooding of karstic networks active during the glacial period; and 3) the sea water mixing with coastal aquifers (saline intrusion) creates submarine source discharge of brackish water (Fleury et al., 2007).

The purpose of the present study is to describe a peculiar coastal karstic system, by combining geophysical surveys, dating methods, geological surface field observations and underground submarine exploration. The studied area is currently characterised by a lowland in a topographic depression where a polje filled by more than $50 \mathrm{~m}$ of lacustrine sediments was discovered. Submarine karst conduits have been explored by speleo-divers from the sea for more than $3 \mathrm{~km}$ of development inland, and their topographic survey suggests that they may be linked with the polje. Geophysical methods are useful for studying heterogeneous karst structure (e.g. Chalikakis et al., 2011; Vadillo et al., 2012). Electric resistivity tomography (ERT) permits the characterization of karstic areas thanks to the contrast in electrical resistivity between resistive low permeability rocks and cavities filled with clayrich sediments (e.g. Siart et al., 2010). Gravimetric survey is used to investigate sub-surface cavities because the density contrast is large between karstified rocks and the filled cavity (Butler, 1984; Styles et al., 2005). The Horizontal-to-Vertical spectral ratio (H/V) method is important for mapping the thickness of lacustrine sediments (e.g. Delgado et al., 2000; Guéguen et al., 2007; Méric et al., 2007), with a strong S-wave velocity difference (velocity ratio $\geq 3.5$ ) between the surface layer and deeper material (Rosenblad and Goetz, 2010).

The combined use of different geophysical methods is powerful for characterising karstic structure (e.g. Pueyo-Anchuela et al., 2011; Štěpančíková et al., 2011), and the comparison of geophysical results with data from drilling allows verification of the interpretations. Moreover, drilled sediments have been dated using complementary absolute and relative dating methods. Identification of reworked nanofossils from sediments allows the determination of the sediment source areas.

\section{Geological setting}

\subsection{Geological setting}

This study focuses on a small alluvial plain at $86 \mathrm{~m}$ altitude in Cassis (Bouches-du-Rhône, Southern France), about half a kilometre wide and $2 \mathrm{~km}$ from the Mediterranean Sea (Fig. 1). This depression is currently downstream of a small topographic catchment area of about $8 \mathrm{~km}^{2}$, rising to $444 \mathrm{~m}$ altitude. The northwestern part of the catchment area is composed of Lower Cretaceous, massive Barremian limestones (Urgonian facies) whilst the southeastern part consists of an Aptian limestone-marl sequence. Structural setting (Debrand-Passard et al., 1984 ) is characterised by a monoclinal series with a local dip around $8^{\circ}$ to the southeast, although specific localized outcrops reach $18^{\circ}$ dip (Fig. 1). To the southeast, the catchment area is limited by the Cenomanian sandstone and limestone cliff, delimiting a separate catchment within the Upper Cenomanian marls. A NW-SE orientated fault separates the southern part of the catchment area from an uplifted Barremian limestone ridge, cut by a gorge where the outlet flows to

(a)

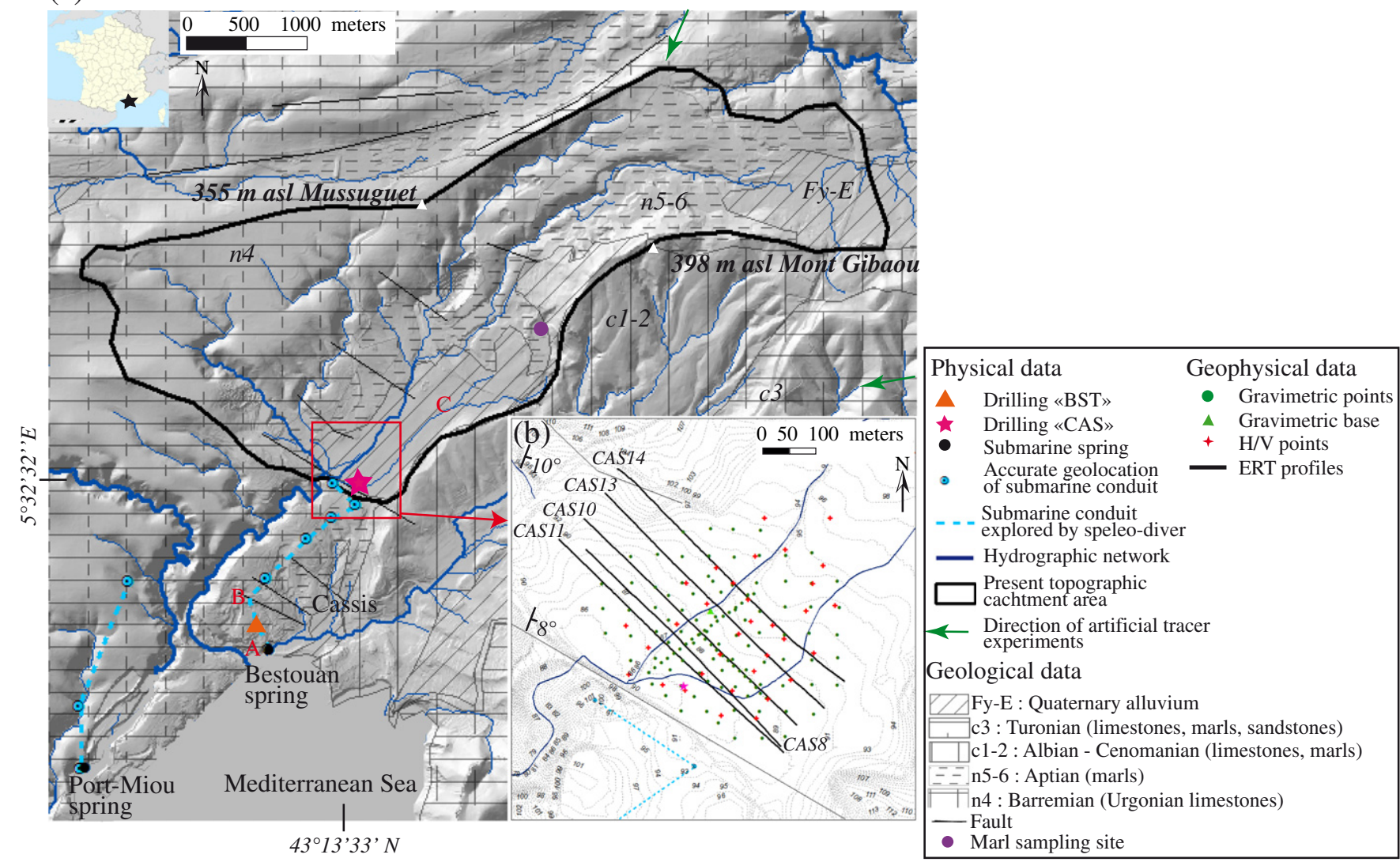

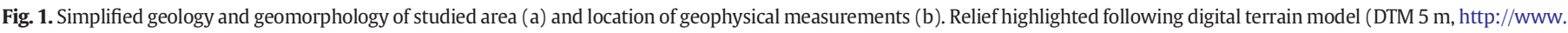

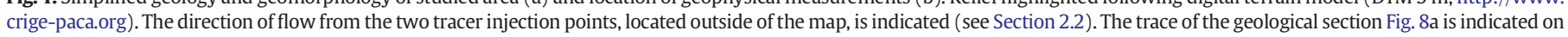
(a) by letters (A, B, C). For further details on sampling site of marls see Table 2 . 
the sea. Quaternary deposits occur within the depression, which was not identified as a polje until the present study.

\subsection{Karst}

The Cassis area is well-known for its karstic geomorphology and "Calanques" which are canyons cut into Urgonian limestones by fluviokarstic processes during the glacial period and presently drowned by sea-level rise. Numerous caves exist in the limestone formations (Early Cretaceous in the western part of the studied area, and Late Cretaceous in the eastern part). Major underground karst features are developed below the current sea level. Two submarine conduits have been explored by speleo-divers: the Port-Miou and Bestouan 'rivers' (Arfib and Douchet, 2011). The Bestouan river, ending at the Cassis port entrance, shows a sub-horizontal conduit, which runs at a depth between 0 and $29 \mathrm{~m}$ bsl with a cross-section ranging between 10 and $30 \mathrm{~m}^{2}$. Its exploration was stopped after $3 \mathrm{~km}$ right on the NW-SE fault which borders the southern boundary of the studied depression (Fig. 1) at sea-level, i.e. about $90 \mathrm{~m}$ below the soil surface. Port-Miou shows also a sub-horizontal conduit (depth between 0 and $30 \mathrm{~m} \mathrm{bsl}$ ), about ten times larger than Bestouan, over a distance of $2 \mathrm{~km}$ from the shoreline followed by a near vertical plunge explored down to $223 \mathrm{~m}$ bsl.

These submarine rivers drain groundwater, forming submarine karstic springs with perennial discharge, which are the main groundwater outlet of the Beausset Unit between Marseille and Toulon. These springs have been extensively studied as they represent a potential resource of freshwater and can be used as proxies for karst evolution and fresh groundwater resources around the Mediterranean Sea (Audra et al., 2004; Blavoux et al., 2004; Arfib et al., 2007; Fleury et al., 2007). The Port Miou and Bestouan springs belong to the same karstic aquifer and are brackish due to seawater intrusion (Tassy et al., 2010). The seawater intrusion occurs at a depth and several kilometres inland, upstream from the terminal explorations by the divers.

The Port Miou and Bestouan springs drain an aquifer probably larger than $400 \mathrm{~km}^{2}$, with still uncertain boundaries. A recent dye tracing test showed a rapid connection (transfer velocity about $1.7 \mathrm{~km}$ per day) between a sinkhole and the springs in the carbonate-siliciclastic Turonian and Coniacian rocks located $12 \mathrm{~km}$ to the east of the studied area (Arfib and Lamarque, 2012) (Fig. 1). It confirms that the springs drain two reservoirs (Arfib et al., 2006): brackish water coming from the deep part of the aquifer through a chimney-shaft, mixed with fresh water flowing in the upper part of the aquifer through vadose, epiphreatic and shallow phreatic conduits. The deep karstic system around the Mediterranean Sea can be related to the Messinian Salinity Crisis (Audra et al., 2004; Mocochain et al., 2006), a sea-level drop of more than $1500 \mathrm{~m}$ acting as the base-level for karst development (Krijsman et al., 1999; Rouchy and Caruso, 2006). Later transgressions and Quaternary sea-level oscillations established a new base-level close to the current sea-level. Cave development through the $2 \mathrm{~km}$-thick Beausset Unit follows the general hydraulic head from north to south, and is also affected by tectonic structures, such as NW-SE faults in the Cassis area.

\section{Materials and methods}

\subsection{Geophysical methods}

A 2-D electric resistivity tomography (ERT) was obtained by employing the ABEM Lund Imaging System using an inverse WennerSchlumberger configuration with 64 steel electrodes spaced regularly at 10 or $9 \mathrm{~m}$ intervals (Fig. 1b). GPS was used to geo-reference datasets. The apparent resistivity was measured using a computer-controlled multi-channel resistivity metre SAS 4000 (Griffiths et al., 1990). RES2DINV software was used to invert ERT data (Loke and Barker, 1995; Rucker et al., 2011). The validity of the obtained resistivity sections is supported by the low RMS error of about $2 \%$ for the 6th iteration.
Gravity data were recorded with a relative micro-gravimeter, model Scintrex CG5, with a $50 \times 50 \mathrm{~m}$ grid, in order to create a high-resolution gravity map (Fig. 1b). The nominal sensitivity is about $1 \mu \mathrm{Gal}$. Coordinates of measurement points were determined using Trimble GPS in a differential mode with an accuracy of $\pm 0.01 \mathrm{~m}$. Gravimetric data require various corrections (Bonvalot et al., 2008; Merlet et al., 2008; Jacob et al., 2010) to obtain accurate gravity anomalies only corresponding to underground density anomalies. Earth solid tide and ocean loading correction were calculated using TSoft Software (van Camp and Vauterin, 2005). To predict the ocean loading, the tool http://froste. oso.chalmers.se/loading (Bos and Scherneck, 2011) was applied using the FES2004 oceanic model (Lyard et al., 2006). The drift of the gravity metre (Martín et al., 2011) was corrected by applying a linear approximation to the data between two measurements at the base station every 3-4 h. Free-air and Bouguer gravity corrections were performed following Blakely (1996). Finally, the average relative gravity over the survey area is subtracted from the Bouguer anomaly at each station. The Bouguer anomaly data were interpolated using the kriging method (with smoothing distance of $100 \mathrm{~m}$ ). Oasis Montaj software (GM-SYS, 2001) allows removal of the regional trend and interpolation of a map of Bouguer anomaly. 2D gravity modelling has been performed using the GM-SYS Profile Modelling Program (Ramadass et al., 2006). The model was constrained with several geological and physical data.

The H/V measurements (Nakamura, 1989) were performed at 38 sites, which were located with a GPS (Fig. 1b). Seismic noise was recorded during at least $30 \mathrm{~min}$ with a $100 \mathrm{~Hz}$ sampling frequency. Each station was equipped with a GSR 24-bit digitiser connected to a LE-3D/5s seismometer. Data were processed with the Sesarray package (http:// www.geopsy.org, e.g. di Giulio et al., 2006; Wathelet et al., 2008). Microtremor records were cut into $60 \mathrm{~s}$ time windows, for which Fourier spectra were computed and smoothed using methods described by Konno and Ohmachi (1998). At each site, the H/V spectral ratios were computed for all selected time windows, and the mean $\mathrm{H} / \mathrm{V}$ curve was determined with standard deviations. The $\mathrm{H} / \mathrm{V}$ curves were interpreted using SESAME (2004) criteria to obtain the fundamental frequency of each site $\left(f_{0}\right)$.

\subsection{Sediment sample and analysis}

Two sedimentary records have been investigated: a 50 m-deep drilling (CAS) in the Quaternary lacustrine sequence from the polje $\left(43^{\circ} 13^{\prime} 33^{\prime \prime} \mathrm{N}, 5^{\circ} 32^{\prime} 32^{\prime \prime} \mathrm{E}\right.$, Fig. 1) and a $50 \mathrm{~cm}$-deep percussion core (BST) coming from the Bestouan river. The CAS drilling was undertaken by CEREGE and the 'Centre de Carottage et de Forage National' (C2FN, INSU) using a SEDIDRILL 250-90 drill. Two cores (of 18 and $50 \mathrm{~m}$ lengths) were obtained $1 \mathrm{~m}$ from each other, with a perfect sedimentary overlap, which allowed us to fill most of the gaps (recovery ratio for lacustrine section: 95\%). BST was obtained by divers through inserting a plastic tube into the conduit floor about $50 \mathrm{~m}$ from the entrance, at $18 \mathrm{~m}$ depth (Fig. 8). CAS and BST drillings were characterised using sedimentological analysis in order to establish relationship between the karstic structure and the submarine spring. Four shallow soundings were also performed by trenching or percussion coring (Cobra system) in four sites around the CAS drilling to confirm the presence of lacustrine deposits.

The global mineralogy of bulk sediment and the mineralogical composition of clay fraction were determined by X-Ray diffractometry (XRD). Samples of 0.5 or $1 \mathrm{~g}$ were dried and crushed in an agate mortar. Bulk samples were analysed without pre-treatment. For clay samples, as the signal strength of carbonates masked the signal of clay, carbonate and organic matter were removed by chemical treatments. Then only the fraction finer than $2 \mu \mathrm{m}$ was kept. Three glass slides were prepared: an untreated control slide, a heated slide $\left(490{ }^{\circ} \mathrm{C}, 4 \mathrm{~h}\right)$ and a slide treated with ethylene glycol. Identification of clay mineralogy is based on changes in the spectral signature after physical or chemical treatment, compared to an untreated control (Moore and Reynolds, 1989; 
(a)

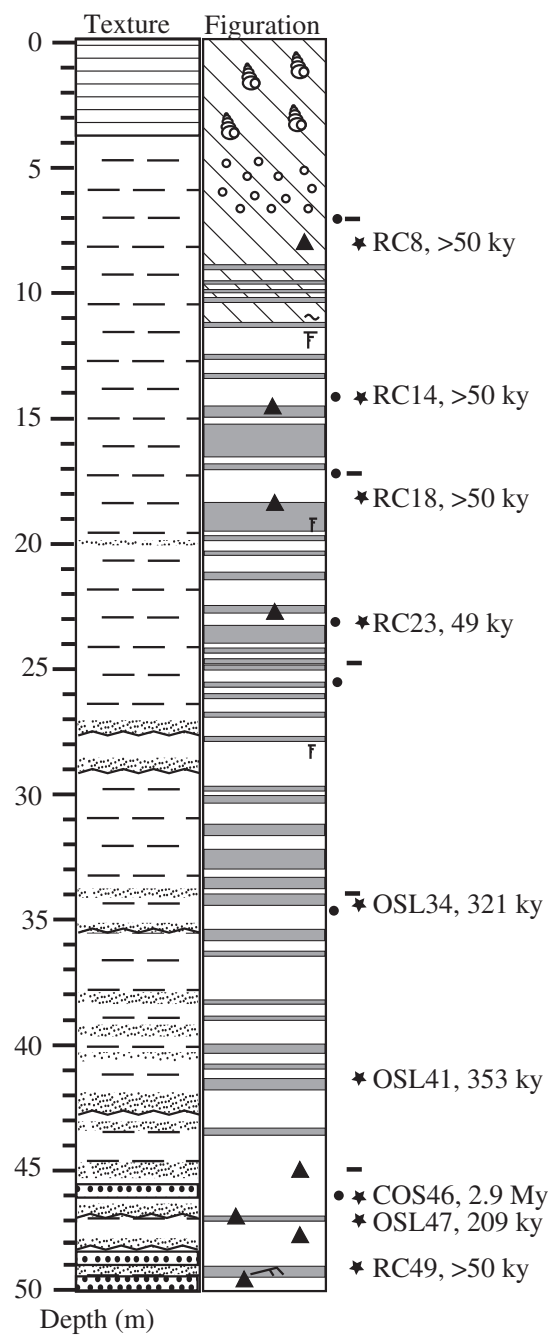

(b)

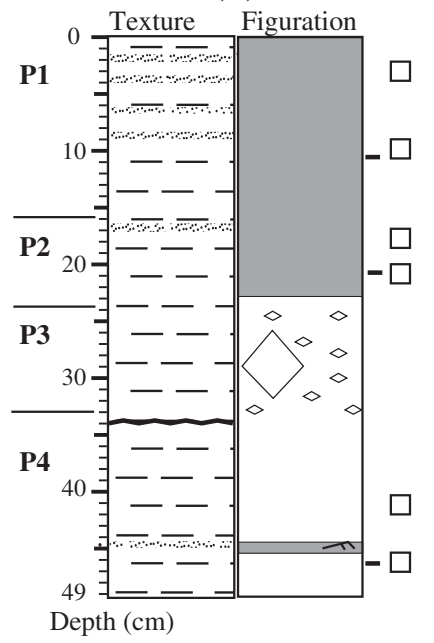

\begin{tabular}{|c|c|c|c|}
\hline \multicolumn{2}{|c|}{ Figuration } & Texture & \multirow[b]{2}{*}{ grey clay } \\
\hline & area affected by & -1 & \\
\hline & horizontal lamina & & silt \\
\hline$\pi$ & Inclined lamina & $\because \cdots$ & \\
\hline m & Erosive contact & & mine sand \\
\hline & Sharp contact & & aptian marl \\
\hline$\Delta$ & Macro-charcoal & & \\
\hline छ & Gasteropods & & \\
\hline $\mathrm{F}$ & Fault & & \\
\hline$\sim$ & Bioturbation & & \\
\hline$\circ$ & Calcite concretion & & \\
\hline$\diamond$ & angular gravel & & \\
\hline 一 & ample for nannofossi & analysis & \\
\hline - & ample for pollen ana & & \\
\hline 4 & ample for dating & & \\
\hline$\square$ & $\begin{array}{l}\text { ample for paleomagn } \\
\text { scale } 1: 1 \text { ) }\end{array}$ & ic study & \\
\hline
\end{tabular}

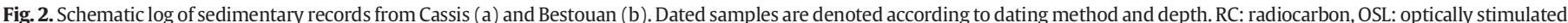
luminescence, COS: cosmogenic nuclides. See Section 4.1 for Bestouan levels (P1-P4) explanations.

Marriner et al., 2011). Semi-quantitative estimations ( \pm 5-10\%; Biscaye, 1965) of the main clay species were based on the height of specific reflections measured on ethylene glycol pattern. Clay and bulk sample XRD patterns were recorded using a Philips PW 1729 X-Ray generator using $\mathrm{K} \alpha \mathrm{Co}$ radiation $(\lambda=1.79 \AA)$ at $40 \mathrm{~mA}$ and $40 \mathrm{kV}$. Data were collected by the step-counting method (step size $0.05^{\circ}$ ) between $2.5^{\circ}$ and $35^{\circ}(2 \theta)$ with a counting time of $5 \mathrm{~s}$ per step.

The $\mathrm{C}_{\text {tot }}, \mathrm{C}_{\mathrm{org}}$, $\mathrm{N}$ and carbonate compositions were determined using a CNS NA 1500 series 2. The standard used for $\mathrm{C}_{\text {org }}$ was an Acetanilide powder $\left(\mathrm{C}_{8} \mathrm{H}_{9} \mathrm{NO}\right.$, containing $71.09 \%$ carbon $)$. Samples of about $30 \mathrm{mg}$, dried and crushed in an agate mortar, were burnt at $1024{ }^{\circ} \mathrm{C}$. The measurement of degassed $\mathrm{CO}_{2}$ and $\mathrm{Nx}$ allows determination of \%Ctot and $\% \mathrm{~N}$. Then samples between 10 and $15 \mathrm{mg}$ were decarbonated with $250 \mu \mathrm{l}$ of $\mathrm{HCl}(1 \mathrm{M})$ at $40{ }^{\circ} \mathrm{C}$ over two days. The determination of degassed $\mathrm{CO}_{2}$ provides \%Corg. \% $\mathrm{CaCO}_{3}$ content was estimated using the following equation: $\% \mathrm{CaCO}_{3}=(\% \mathrm{Ctot}-\%$ Corg $) * 8.33$.

\subsection{Dating and paleontological methods}

Radiocarbon dating ( 6 charcoal samples) was performed at the Poznań Radiocarbon Laboratory (Poland) and at the ARTEMIS facility (Saclay, France). Charcoals and wood fragments were identified by B. Talon at IMBE (Aix-en-Provence, France) before dating.
Magnetostratigraphic relative dating is based on characteristic features of the magnetic field recorded during sedimentation (polarity chrons and excursions; e.g. Demory et al., 2005). Natural Remanent Magnetization (NRM) was measured with a 2G Enterprises DC-SQUID cryogenic magnetometer $2 \mathrm{G} 760 \mathrm{R}$ equipped with on-line alternating field demagnetization. Discrete $8 \mathrm{~cm}^{3}$ cubic samples were used from BST whilst a continuous record was obtained from CAS using Uchannels. Direction of characteristic NRM was determined by principal component analysis of the AF demagnetization curve (Kirschvink, 1980). Optically Stimulated Luminescence (OSL) dating was carried out on quartz mineral grains at the Luminescence Dating Laboratory, Research Laboratory for Archaeology and the History of Art, University of Oxford (England). Three samples for OSL dating were collected from half cores which had previously been opened in daylight. Core sections showing a 5-10 cm sandy layer plus a few centimetre of the upper and lower clays were selected for dating. In order to avoid the inclusion of bleached mineral grains, the exposed surface of the cores (circa $1.5 \mathrm{~cm}$ ) was removed under low intensity filtered LED lighting (emitting at $\sim 588 \mathrm{~nm}$ ). OSL measurements were performed on coarse sand sized grains (180-255 $\mu \mathrm{m}$ ) extracted from the sediment using standard preparation procedures (Mejdahl, 1985). OSL measurements were performed on an automated Risø luminescence reader (BøtterJensen, 1997; Bøtter-Jensen et al., 2000) using a SAR post-IR blue OSL 


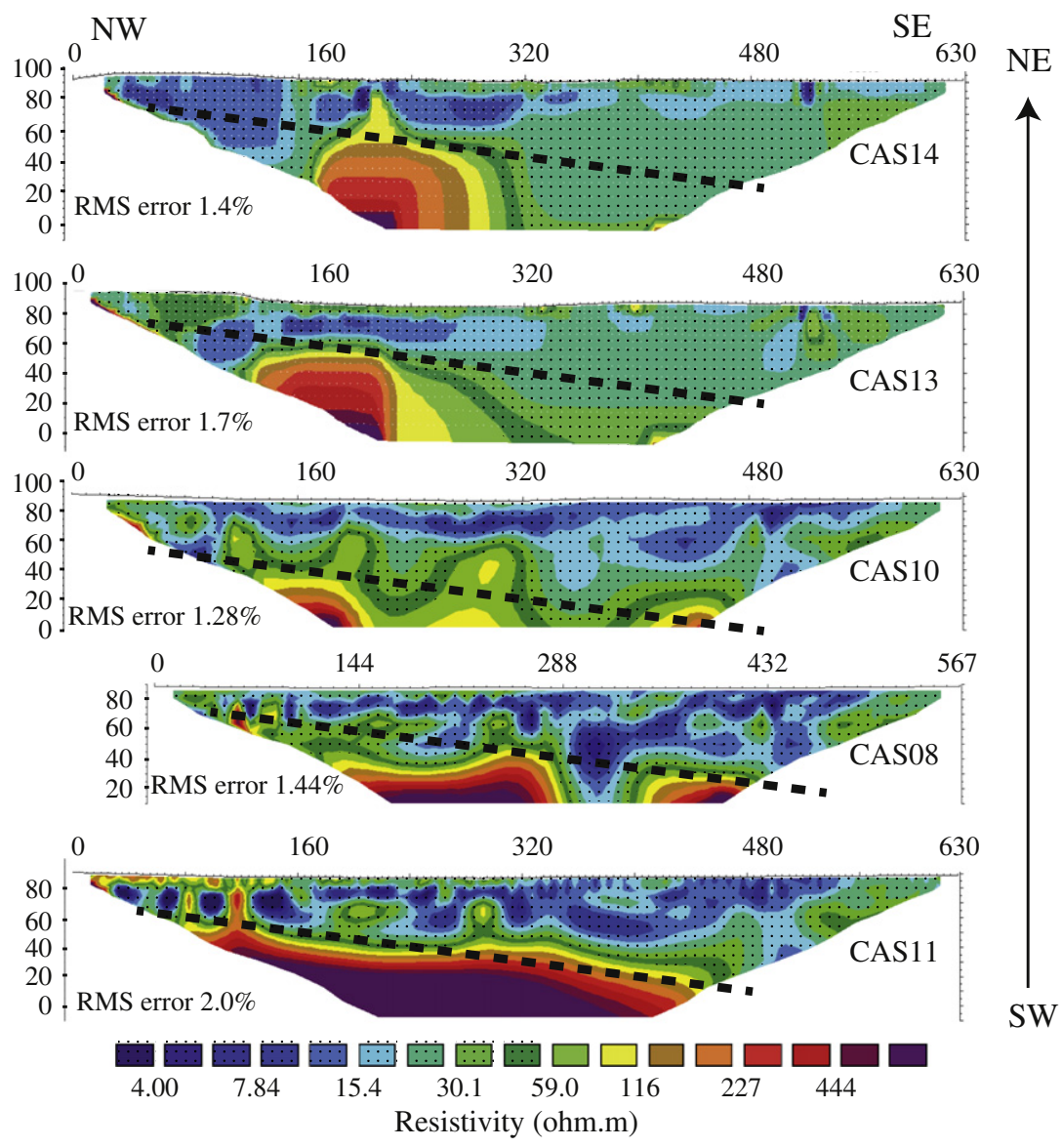

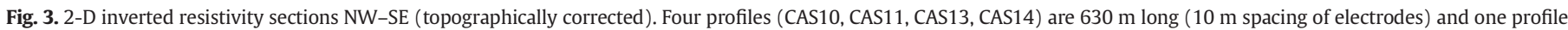

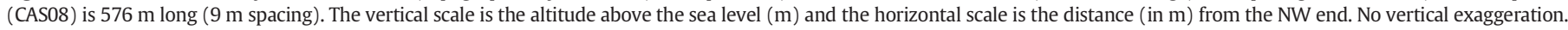
Pre-karstic interpolated interface between marls and limestones is indicated by a dotted line.

measurement protocol (Murray and Wintle, 2000; Banerjee et al., 2001; Wintle and Murray, 2006). Dose rate calculations are based on Aitken (1985). The OSL age estimates include an additional 3\% systematic error to account for uncertainties in source calibration. One sample for cosmogenic nuclide dating $\left({ }^{26} \mathrm{Al} /{ }^{10}\right.$ Be burial method) sample was prepared at CEREGE-LN2C and measured at ASTER, the French accelerator mass spectrometry (AMS) facility (Aix-en-Provence, France). Quartz ( $50 \mathrm{~g})$ obtained after decarbonation of the fine sandy fraction $(100-400 \mu \mathrm{m})$ from a thick sand layer near the core base was then treated following the protocol of sample preparation for ${ }^{26} \mathrm{Al}$ and ${ }^{10} \mathrm{Be}$ measurement (Braucher et al., 2000).

The pollen record (10 samples) was studied in IMBE (France). Because of the poor concentration of sporo-pollinic material, samples were prepared using the method of Takeshi (Nakagawa et al., 1998) using heavy liquid (density $=1.96$ ). Calcareous nanofossils were identified at the University of Lyon (LGLTPE, France) in order to characterise the source of karstic sediment in BST. Samples were prepared as smear slides following the technique described in Bown and Young (1998), and slides were analysed under a Leica optical microscope, with crossed polars, and $1000 \times$ magnification. Taxonomic determinations and age assessments were based on Bown (1998).

\section{Sedimentary and geophysical results}

\subsection{Sedimentary record from Cassis and Bestouan}

Detailed analysis of the sedimentary sequence is beyond the scope of the present publication. The information relevant to the geomorphological interpretation will thus be briefly summarized. In the polje CAS core the first $4.5 \mathrm{~m}$ corresponds to Holocene alluvium, whilst from 4.5 to $50 \mathrm{~m}$ finely laminated lacustrine sediment was observed (Fig. 2). At the bottom, the contact with massive Cretaceous marl was sampled over a few centimetre. The upper $5 \mathrm{~m}$ of lacustrine deposits was yellowish brown and oxidized because of redox phenomena due to the vertical oscillation of the watertable and pedogenesis occurring since lake filling. Alteration of the sediment prevents the identification of lamina in that upper part. Lamination is (sub)horizontal, except in the last few metres close to the bottom. The up to $15^{\circ}$ dip of bottom laminae is probably related to subsidence of the bedrock at the beginning of sedimentation. The lacustrine sediments show considerable homogeneity in colour, texture and composition. Grey sediments are indicative of a reducing environment (sulphides have been identified). The lacustrine sediments are carbonate-rich and poor in organic matter (Table 1). XRD analyses undertaken on bulk samples indicated that global mineralogy is dominated by calcite $\left(\mathrm{CaCO}_{3}\right)$, dolomite $\left(\mathrm{Ca}, \mathrm{Mg}\left(\mathrm{CO}_{3}\right)_{2}\right)$, quartz $\left(\mathrm{SiO}_{2}\right)$ and clay. XRD of the clay fraction shows the presence of smectite, illite and kaolinite.

The BST core can be divided in four parts. P1, from 0 to $17 \mathrm{~cm}$ depth, is composed by laminated and ocher clay. Colour and low $\mathrm{CaCO}_{3}$ content at the top of P1 (from 3 to 19\%) point towards oxidation and decarbonation of the sediment. From 0 to $10 \mathrm{~cm}$ (P1a) laminae are only due to changes in texture (clay/sand) whereas from 10 to $17 \mathrm{~cm}$ (P1b) laminae are caused by changes in colour (few grey laminae in ocher sediment). $\mathrm{P} 2$, from 17 to $23 \mathrm{~cm}$, is composed by laminated clay. Clay is mostly grey with some ocher levels and has a higher percentage of $\mathrm{CaCO}_{3}$ (from 25 to 35\%). From 17 to $20 \mathrm{~cm}$ (P2a), clay is dark grey whereas from 20 to $24 \mathrm{~cm}$ (P2b) clay is light grey. P3, from 23 to $34 \mathrm{~cm}$, is 
(a)
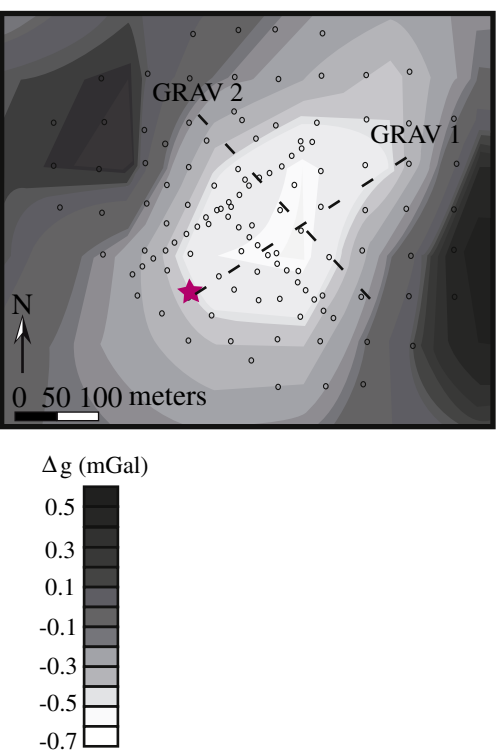

(b)
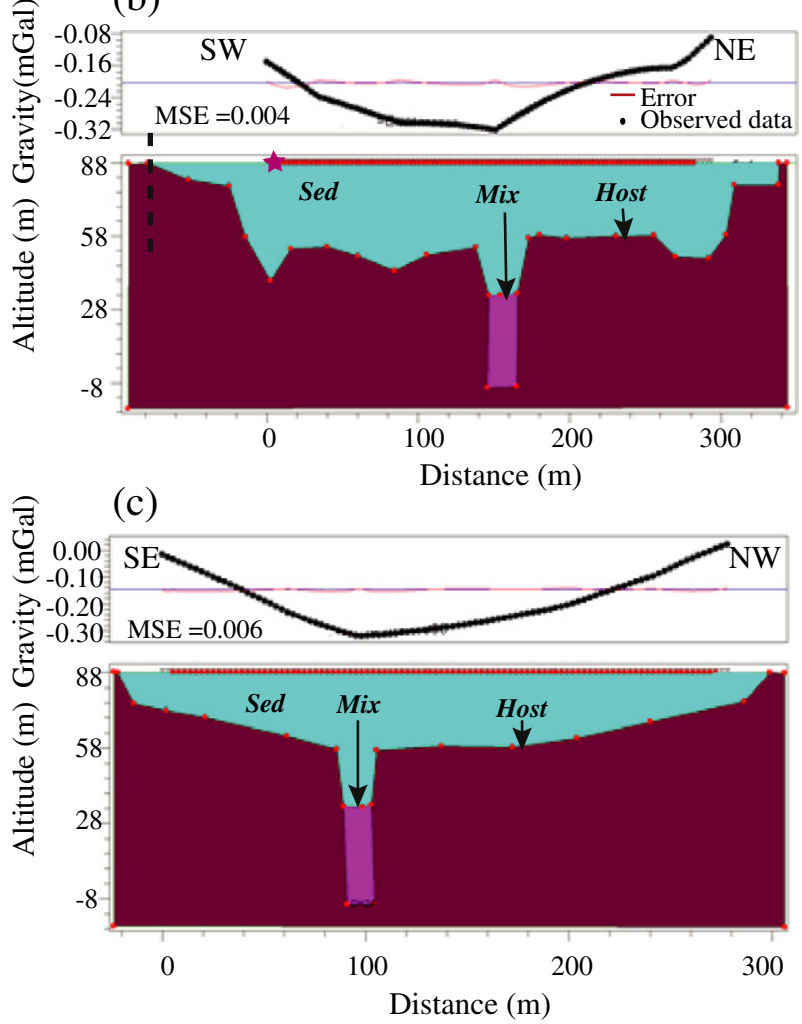

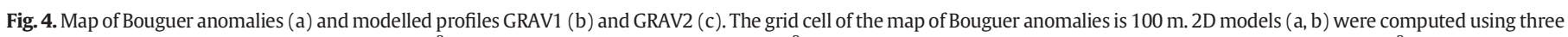

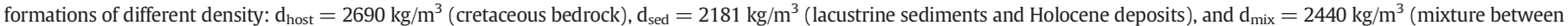
sediments and bedrock). Drilling "CAS" (star) and fault (dotted line) are localized on GRAV1.

(a)

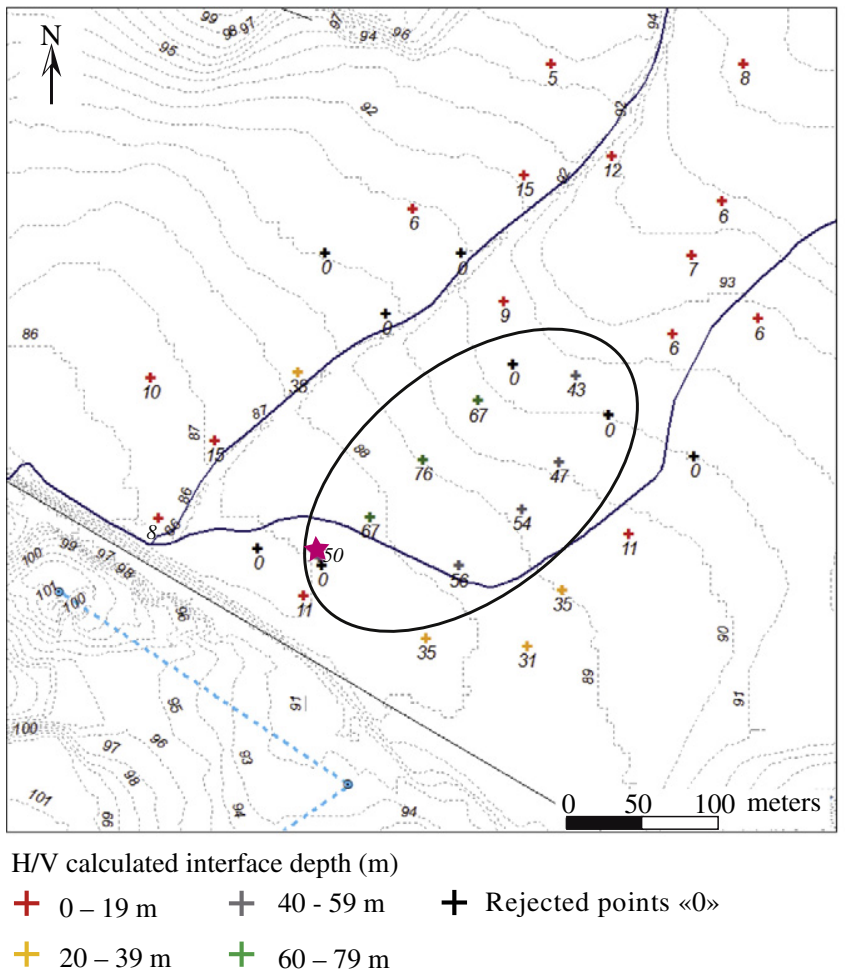

(b) Peak $\mathrm{f}_{0} \sim 3 \mathrm{~Hz}$
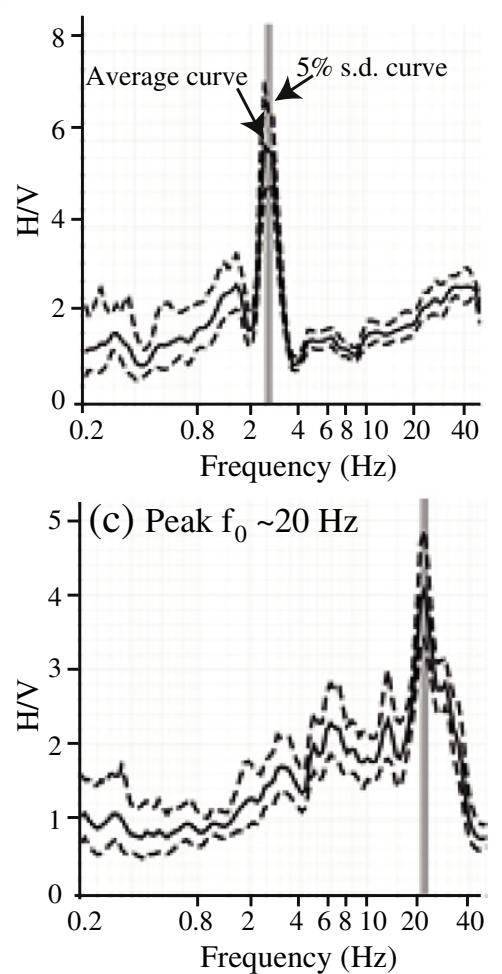

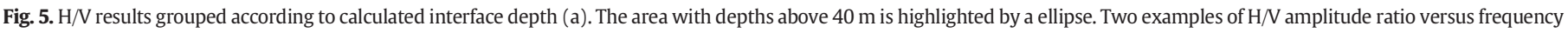

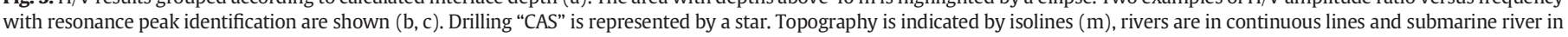
dotted line. 


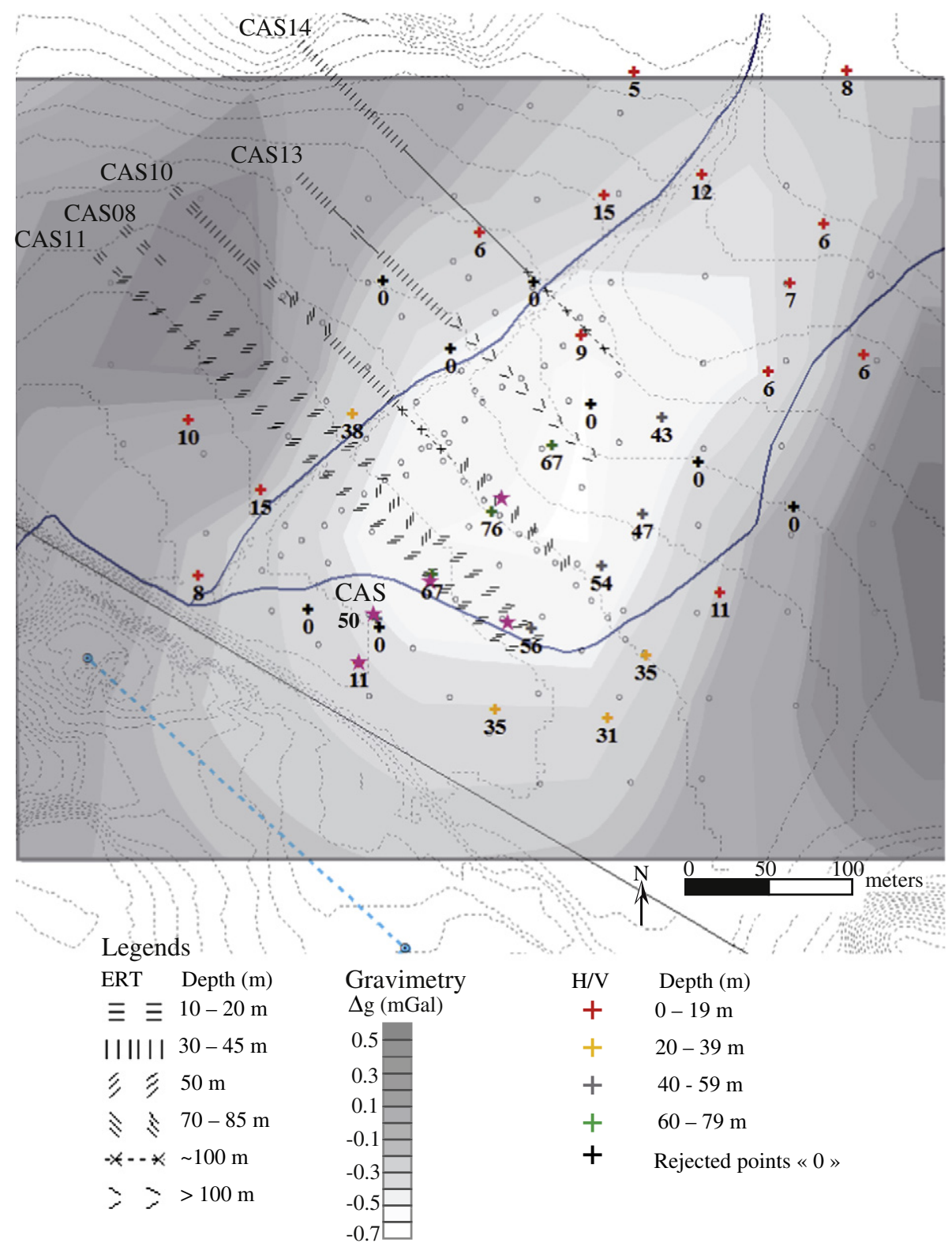

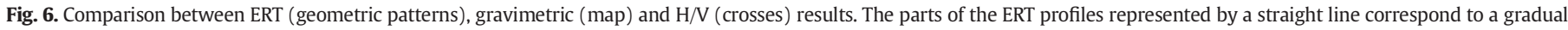
transition between the two depth classes which surround it. Drilling "CAS" and five shallow $(\sim 3 \mathrm{~m})$ additional drilling are located by a star.

composed by ocher clay with numerous angular pebbles and large sand and gravel fractions. P4, from 34 to $49 \mathrm{~cm}$, is composed by ocher clay, with some sandy laminae.

This succession implies that a high energy event was recorded during P3, with a subsequent fine sediment input (P2) of composition and origin different than the previous and later input (P1 and P4). The observed difference (higher carbonate content and reduced environment) indicates rapid sedimentation of a sulphide- and/or organicrich material.

\subsection{ERT survey}

Six ERT profiles with NW-SE orientation were measured (Fig. 3). The topographic variations, which were also considered in the inversion model, are quite small $(\mathrm{dh}=5 \mathrm{~m})$. According to Samouëlian et al. (2005) the range of resistivity of unaltered and altered limestone is very wide, between 50 and $5000 \Omega \cdot \mathrm{m}$ whereas lacustrine sediment and marl have low resistivity $(5-70 \Omega \cdot \mathrm{m})$ (e.g. Metwaly and AlFouzan, 2013; Nordiana et al., 2013). Apart from very porous or highly fractured saturated limestones, not present in our study, clay-poor slightly fractured limestone resistivity is assumed $>100 \Omega \cdot \mathrm{m}$. ERT is unable to discriminate between formations having similar electrical properties, and the resistivities of marl and Quaternary lacustrine sediment may be too close to distinguish the boundary between both formations. ERT data are only able to locate the boundary between Barremian limestone and the overlying marls or Quaternary formations.

2D pseudo-sections are described from north to south. The description is done using the distance from the electrode located at the NW end (designated 0). On the NW end of profiles, the massive limestone levels are nearly outcropping and should plunge about $10^{\circ}$ below the Aptian marl or any Quaternary filling. The expected top of limestone layer without the impact of karst/dissolution phenomena is indicated by dotted line in Fig. 3. Taking the $100 \Omega \cdot \mathrm{m}$ value as the lower limit for limestones, one could see in CAS11 that a limit between low resistivity and high resistivity material can fit with the expected top of limestone 


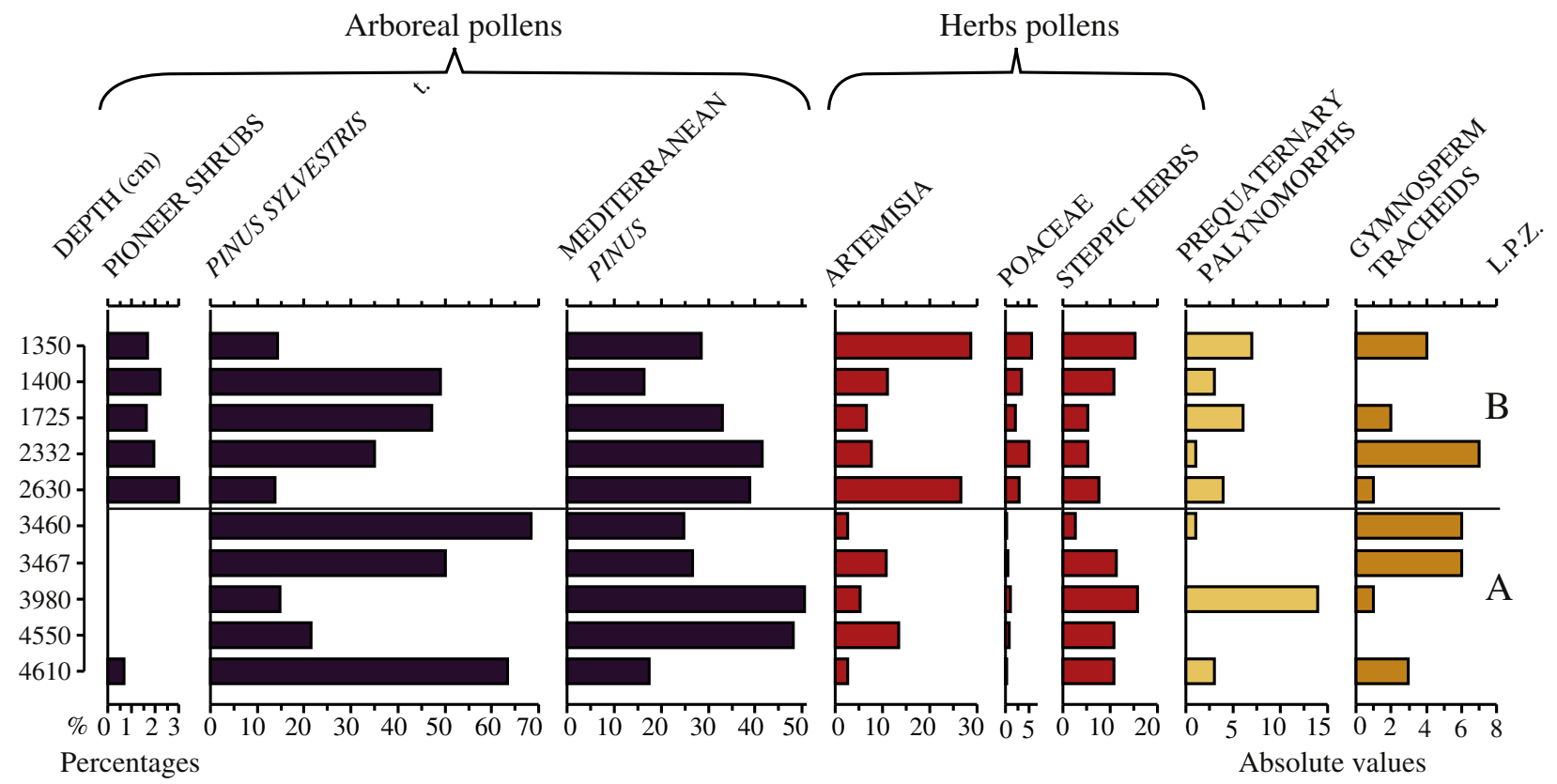

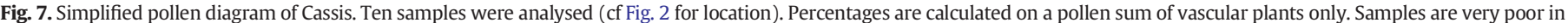

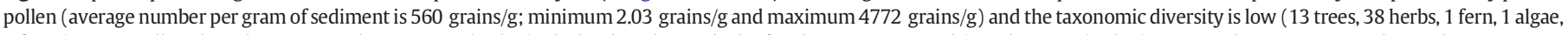

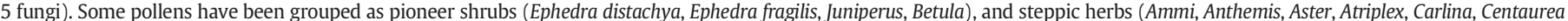

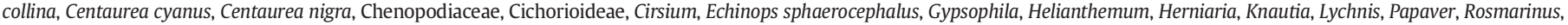
Rumex, Sinapis, Succisa and Thalictrum). L.P.Z. means Local Pollen Zone, A indicates a glacial climatic dynamics and B a lateglacial climatic dynamics.

layer. In other ERT profiles, limits do not match with expected the limestone tops, thus suggesting fracturing and/or dissolution of the limestones and infilling by Quaternary deposits in karstic structures. Major infillings down to more than $80 \mathrm{~m}$ depth are identified between electrodes 300 and $350 \mathrm{~m}$ in CAS 8, 13 and possibly 14.

Two distinct parts are visible on profile CAS11, the closest profile to the drilling. There is a deep continuous resistivity layer (from 100 to $440 \Omega \cdot \mathrm{m})$ which is covered by a less resistive layer $(<50 \Omega \cdot \mathrm{m})$. The more resistive layer has a dip characteristic of the regional limestone substratum. Locally, the dip is not constant and it sharply increases around the electrode located at $320 \mathrm{~m}$. The limestone is covered by marl and clay (less resistive). The two layers are observed on the CASO8 profile but their morphologies change. The more resistive layer is cut by the lower resistivity layer between electrodes located at 290 and $340 \mathrm{~m}$. It forms a narrow funnel-shaped structure in the substratum which is filled with a low resistivity material. The depth of the structure is greater than $80 \mathrm{~m}$. CAS10 profile shows a general rise of the high-resistivity material and particularly between electrodes located at 270 and $320 \mathrm{~m}$ and between electrodes located at 185 and $230 \mathrm{~m}$. On CAS13 and CAS14 profiles, structures and resistivity variations are similar.

In the near-surface layers of Holocene sediments one can see a steady decrease of average resistivity from NE to SW. The decreasing resistivity corresponds to a more water-rich subsurface layer, in agreement with the lower altitude and accumulation of water, as well as thicker Holocene deposits.

\subsection{Gravimetric survey}

The Bouguer anomaly map (Fig. 4a) shows that after corrections gravity has a small amplitude range of variation ( $1.2 \mathrm{mGal}$ ) from -0.7 to $0.5 \mathrm{mGal}$. A central band, oriented SW-NE, is highlighted by a negative anomaly which indicates the presence of a low density material, corresponding to the lacustrine sediments. This negative anomaly is elongated SW-NE and is about $400 \mathrm{~m}$ long and $200 \mathrm{~m}$ wide. It is flanked to the east and west by two positive anomalies, indicating the presence of high density material near the surface corresponding to the Cretaceous bedrock (marl and massive limestone).
The two 2D gravity models (GRAV1 and GRAV2) permit characterization of the morphology of the deep karstic structure. These are composed of three compartments: "Sed" represents lacustrine sediments overlain by Holocene deposits; "Host" is the bedrock and "Mix" a mixture between lacustrine sediments and bedrock. Profile GRAV1 (Fig. 4b) through the centre of the negative anomaly follows the SW-NE direction of elongation and is constrained in the SW extremity by the drilling information and the presence of the fault, and by the density of the sediments and bedrock. Measured lacustrine sediment density is $2180 \mathrm{~kg} / \mathrm{m}^{3}$ (stereopycnometre from Quantachrome Instruments, $n=10$ ) The Aptian marl and Barremian limestone densities used are $2690 \mathrm{~kg} / \mathrm{m}^{3}$ (Fournier et al., 2011). Independent constraints are a $50 \mathrm{~m}$ thickness of lacustrine sediments at the CAS core position and the vertical fault putting into contact bedrock and lacustrine sediments. At the southwestern end of the GRAV1 profile, a significant and abrupt decrease in the depth of the sedment/berbrock boundary is visible. The shape of the polje is slightly asymmetrical, with a deepening towards the SW. The part where the structure is deeper than $30 \mathrm{~m}$ has a SW-NE extension of about $340 \mathrm{~m}$. The central area of highest negative anomaly can be modelled by a narrow vertical structure of about $15 \mathrm{~m}$ width and $90 \mathrm{~m}$ depth. It is modelled by an intermediate density material between lacustrine sediment and bedrock density, which indicates a probable filling by blocks of limestone and marl, clogged with clay coming from the erosion of the watershed. Such a mixture, in indeterminate proportions, of limestone, marl and clay, would have resulted in the formation of a level with a density ranging between 2180 and $2690 \mathrm{~kg} / \mathrm{m}^{3}$. For this model, the density for the mixture corresponds to $50 \%$ clay and $50 \%$ bedrock, i.e. $\mathrm{d}=2440 \mathrm{~s} / \mathrm{m}^{3}$. This interpretation is not unique and an alternative model lacking the intermediate density formation and showing a more conical shape is also possible. However, the first interpretation is more in agreement with the formation scenario described in the following text. Profile GRAV2 (Fig. 4c), oriented NW-SE, is perpendicular to GRAV1 and also crosses the centre of the negative anomaly. The structure is again about $300 \mathrm{~m}$ long but the part deeper than $30 \mathrm{~m}$ is much narrower. 


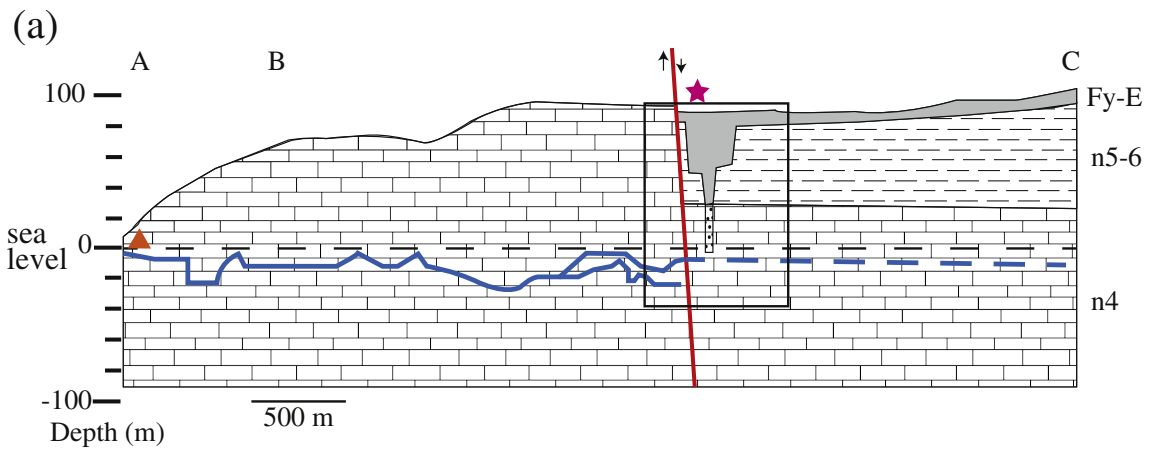

(b)
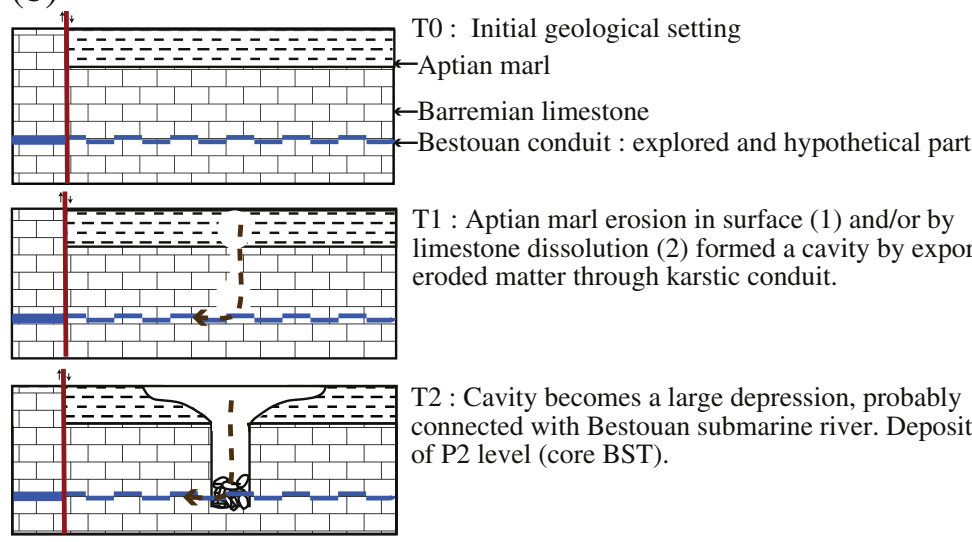

T1 : Aptian marl erosion in surface (1) and/or by limestone dissolution (2) formed a cavity by exporting eroded matter through karstic conduit.

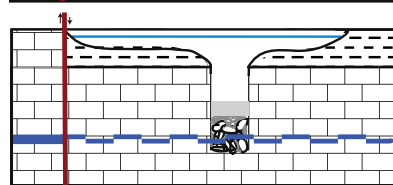

T3 : Depression is clogged by clays, which creates a lake. connected with Bestouan submarine river. Deposition of P2 level (core BST).

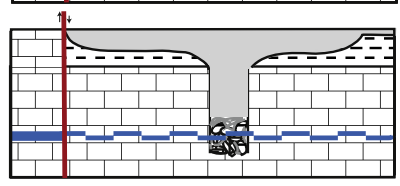

T4 : Lake is filled with sediments.

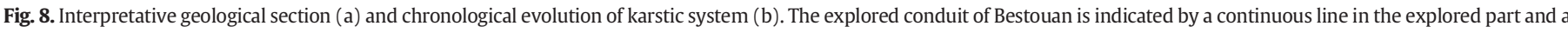

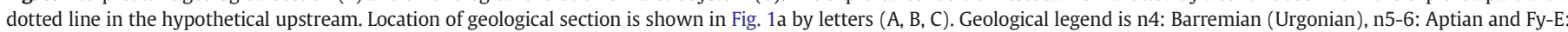
Quaternary alluvium. Location of cinematic section is shown by the rectangle. Drilling "CAS" is represented by a star and drilling "BST" by a triangle.

\section{4. $\mathrm{H} / \mathrm{V}$ data}

Quaternary sediments and their Cretaceous marls and limestones substratum are characterised by S-wave velocity of $200-600 \mathrm{~m} / \mathrm{s}$ (Bièvre et al., 2011) and 2000-3500 m/s (Dvorkin et al., 2001;
Fournier et al., 2011), respectively. This velocity contrast is large enough to provide a significant H/V peak (Rosenblad and Goetz, 2010). Treatment of $\mathrm{H} / \mathrm{V}$ curves can integrate all horizontal components or use a specific azimuth in order to minimize 2D effects. Such effects are linked to surface and interface topographies. The NE-SW azimuth, which

Table 1

Mineralogical and chemical data from Cassis paleolake (core CAS), Bestouan underground river (core BST) and Aptian marls.

\begin{tabular}{|c|c|c|c|c|c|c|c|c|c|c|}
\hline ID & Depth $(\mathrm{cm})$ & Level & Smectite (\%) & Illite (\%) & Kaolinite (\%) & Chlorite (\%) & Water (\%) & $\% \mathrm{C}_{\text {tot }}$ & $\% \mathrm{C}_{\text {org }}$ & $\% \mathrm{CaCO}_{3}$ \\
\hline BST 1 & 3 & P1 & 33 & 45 & 11 & 11 & 40 & 0.46 & 0.14 & 2.64 \\
\hline BST 2 & 11 & $\mathrm{P} 1$ & 59 & 30 & 5 & 6 & 46 & 2.84 & 0.53 & 19.17 \\
\hline BST 3 & 17 & P2 & 32 & 46 & 11 & 11 & 55 & 3.87 & 0.71 & 26.32 \\
\hline BST 4 & 20.5 & $\mathrm{P} 2$ & 48 & 35 & 11 & 6 & 38 & 4.61 & 0.60 & 33.44 \\
\hline BST 5 & 41.5 & P4 & 20 & 64 & 16 & 0 & 28 & 2.00 & 0.13 & 15.64 \\
\hline BST 6 & 46.5 & P4 & 44 & 36 & 8 & 12 & 27 & 1.95 & 0.09 & 15.46 \\
\hline \multirow[t]{4}{*}{ CAS } & Mean & - & 70 & 20 & 10 & 0 & 21 & 6.17 & 0.49 & 47.26 \\
\hline & $\sigma$ & - & 12 & 8 & 6 & 0 & 2.28 & 0.89 & 0.13 & 8.62 \\
\hline & Max & - & 90 & 33 & 22 & 0 & 26 & 7.80 & 0.70 & 62.00 \\
\hline & Min & - & 46 & 6 & 4 & 0 & 18 & 4.38 & 0.30 & 38.00 \\
\hline Mf & - & - & 29 & 38 & 33 & 0 & $<1 \%$ & 9.04 & 0.32 & 72.60 \\
\hline $\mathrm{Ma}$ & - & - & 76 & 13 & 11 & 0 & 22 & 7.62 & 0.22 & 61.64 \\
\hline
\end{tabular}

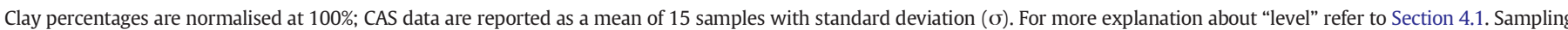
location of fresh marls (Mf) and material resulting from the weathering of marls (Ma) are located in Fig. 1a 
Table 2

Radiocarbon and ${ }^{26} \mathrm{Al} /{ }^{10} \mathrm{Be}$ dating (a), and OSL dating (b) results of Cassis paleolake core.

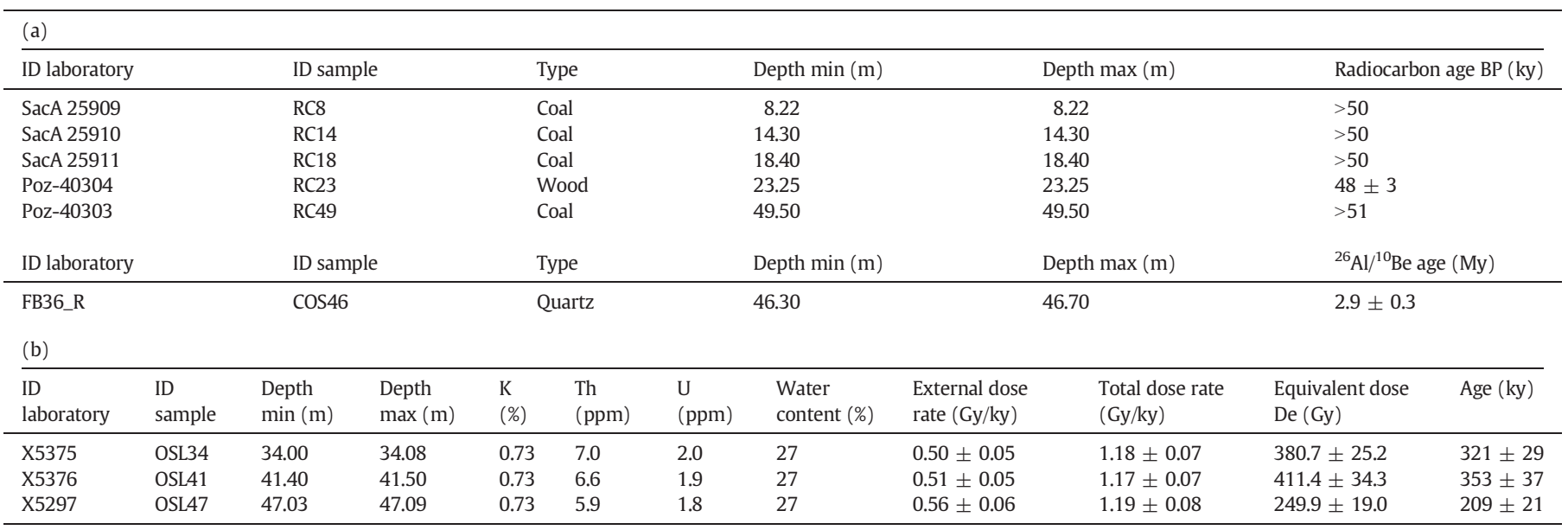

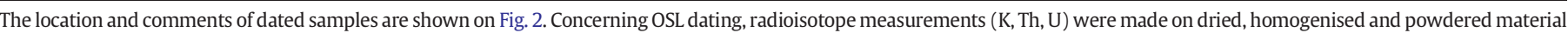

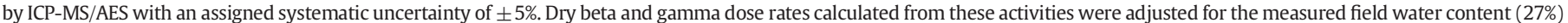

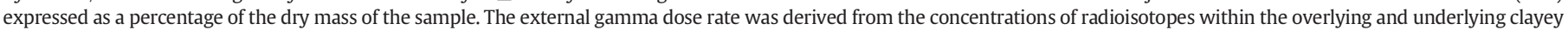
sedimentary units which bracket the sandy layers where the OSL samples were collected. An inflated systematic error of $10 \%$ was attached to the external dose rate calculations.

corresponds to the direction of the valley and elongation of gravimetric data, was chosen for data processing. Data are presented in Fig. 5. The peak values of $\mathrm{H} / \mathrm{V}$ ratio range between 2.2 and 21.96. Eight sites (over a total of 38) were discarded after treatment, either because they yield no well-defined peak or because the geometry of the peak did not fulfil the SESAME criteria (width and height). The frequencies obtained vary between 2 and $32 \mathrm{~Hz}$. Most data are below $5 \mathrm{~Hz}(44 \%)$ or between 13 and $24 \mathrm{~Hz}$ (48\%), with a single site showing a higher frequency. The period of the day during which measurements are taken may affect the results due anthropogenic seismic noise (Cara et al., 2010). Two points were measured at night (S5N and S4N) in order to control the validity of peaks measured during the day. $\mathrm{S} 4 \mathrm{~N}$ is located in the same place as S3P2, which was measured during the day. The obtained frequencies are very close: 2.90 and $2.92 \mathrm{~Hz}$, respectively.

S4N is close to the CAS drilling, and allowed determination of the velocity of the surface layer. At this point, the depth of the bedrock $(\mathrm{h})$ is $50 \mathrm{~m}$ and frequency $\mathrm{f}_{0}$ is $2.90 \mathrm{~Hz}$. The velocity (Vs) is deduced with the following formula: $\mathrm{f}_{0}=\mathrm{V}_{\mathrm{s}} /(4 * \mathrm{~h})$. So, the calculated velocity Vs is $581 \mathrm{~m} / \mathrm{s}$. This value is in accordance with the known velocities of wave propagation in clays (Bièvre et al., 2011). Using this calibration point, the depth of substratum can be computed for the other measurement points. It ranges between 4.5 and $73 \mathrm{~m}$. The two frequency groups mentioned above correspond to depths over $29 \mathrm{~m}$ and in the $6-11 \mathrm{~m}$ range, respectively. The deep group is concentrated in the central and SW part, whilst the shallow group is concentrated in the NE and periphery of the map.

\section{Discussion}

\subsection{Geomorphology of the polje}

The aim of the study was to delineate the morphology of a buried karstic structure and understand the mechanisms of its formation and connection with a submarine karst network. Comparing the results from three geophysical methods based on different properties improves the interpretation of the data. None of the three methods used alone can clearly determine the boundaries between the three formations present: Quaternary sediments, limestones and Cretaceous marl bedrock. Due to similar electrical resistivities, marl and clay are not distinguished on ERT profiles. Gravimetric study does not differentiate between marl and limestone because of similar densities. The H/V method, like gravimetry, gives the depth of bedrock and lacustrine sediment boundary. The area covered by the ERT survey is smaller than that covered by gravimetric survey and $\mathrm{H} / \mathrm{V}$ methods, but the comparison of the results shows that the three methods give coherent results. The results of the ERT profiles and Bouguer anomaly map overlap well, qualitatively (Fig. 6). However, the ERT depth is usually greater than the modelled depth from gravimetry, especially towards the NE. This may be attributed to marls and suggests that the thickness of marl increases towards NE, moving away from the fault. Furthermore, it is possible to interpolate the theoretical depth of the surface contact between marl and limestone, not taking into account karstic structures. With the hypothesis of a clear interface between marl and limestone and a dip of $\sim 8 / 10^{\circ} \mathrm{E}$ (Fig. 3), the depth of marl/limestone boundary obtained is about $45-57 \mathrm{~m}$ below the ground surface within the polje area (at drilling CAS).

In the southwest, the data from the three methods agree well within uncertainties. All H/V-derived depths greater than $30 \mathrm{~m}$ are concentrated in the deeper area indicated by gravimetry, with the largest values fitting well with the gravity minimum. The only discrepancy concerns a H/V depth of $9 \mathrm{~m}$ determined on the CAS14 profile whilst gravity and ERT indicate a deep interface. This may be due to the presence of a discontinuity within the Quaternary sequence or unsuitable $\mathrm{H} / \mathrm{V}$ spectra.

Geophysical observations can be used to determine the general shape of the bedrock of the paleolake, and so to give an estimation of the volume of sediment required to fill the polje. Based upon gravimetric modelling, the shape of the polje can be approximated using simple geometric forms: 1) a narrow vertical structure, representing a collapsed sinkhole or any alternative way to connect the surface to the karstic network at sea level within the massive limestone; and 2) a larger volume, representing the extension of the paleolake related to the erosion of marl through the sinkhole. The general shape of the karstic structure is a similar to a large funnel (Fig. 8), deeper at the centre than at the edges (Fig. 6) and filled by lacustrine sediments. The polje dimensions are about $340 \mathrm{~m}$ long, $300 \mathrm{~m}$ wide and $40 \mathrm{~m}$ average depth. Using these dimensions the volume of sediment filling the polje is about $4 \times 10^{6} \mathrm{~m}^{3}$ (neglecting the central sinkhole volume). Although this simplified calculation minimizes the complexity of the structure of karst depression, it should provide a correct order of magnitude.

Moreover, geophysical studies and sedimentary observations give information about paleolake water depth. Lacustrine sediments contain abundant Cretaceous microfossils but are very poor in Quaternary 
organisms such as ostracods or diatoms. There are no traces of bioturbation (except one at $11 \mathrm{~m}$ ). The lack of diatoms, which are very common in lacustrine sediments, is due to the carbonate-rich nature of the sediment (e.g. Lamb et al., 2007 ). The grey colour of the sediment is characteristic of anoxic sediment, rich in sulphides (van Geen et al., 2003). The sediment lamination also indicates the lack of currents (e.g. waves-induced currents) which would homogenise the sedimentary deposits and oxygenate the water column, and is concordant with sediment anoxia. The sedimentology thus indicates a deep depositional environment (e.g. Tudryn et al., in press). Based on the near-surface presence of lacustrine sediment in all coring points, the surface of the paleolake was once at a present altitude of at least $90 \mathrm{~m}$ a.s.l (altitude of lacustrine sediment cored in the most northward point), thus constraining the altitude of the paleo-outlet.

\subsection{Sedimentary record chronology}

Samples for radiocarbon dating obtained from the lacustrine sediments (Table $2 \mathrm{a}$ ) are all beyond the limit of the technique, about $49 \mathrm{ky}$ (Donahue, 1995). One sample (RC23 at $23.13 \mathrm{~m}$ depth) provides a date of $48 \pm 3 \mathrm{ky}$ which could be due to minor, more recent ${ }^{14} \mathrm{C}$ contamination. Therefore, the entire period of lacustrine sedimentation, and moreover karstic structure formation, can reasonably be assumed to be older than $50 \mathrm{ky}$. Continuous paleomagnetic investigations (Romey, 2013) reveals normal polarity throughout the sequence, indicating a Brunhes age $(<780 \mathrm{ka})$ without any record of geomagnetic excursion. Three OSL dates obtained from 34.04, 41.45 and $48.40 \mathrm{~m}$ depth provided age estimates of $321 \pm 29$ ky (MIS 9-10), $353 \pm$ $37 \mathrm{ky}$ (MIS 9-10) and $209 \pm 21 \mathrm{ky}$ (MIS 6-7), respectively (Table 2b). Optical dating is used to determine burial ages of sediments that were exposed to sunlight prior to deposition. However, OSL dates can be biased by many factors (Bradley, 1999) and one of the main limitations is the possibility of insufficient resetting of the luminescence signal. Partially bleached sediment may contain a mixture of grains carrying different levels of residual signals, and this can lead to an age overestimation (Böse et al., 2012). In this study, the small size of the watershed $\left(\sim 8 \mathrm{~km}^{2}\right)$ would imply a short transport time which could reduce the likelihood of a full resetting of the quartz OSL signal at deposition. The associated low ${ }^{26} \mathrm{Al} /{ }^{10} \mathrm{Be}$ ratio $(1.58 \pm 0.26)$ measured in a sample of quartz from a depth of $46 \mathrm{~m}$ suggests a minimum burial age of $2.9 \mathrm{My}$, which is inconsistent with other data within the core. This implies that the quartz grains have been buried in a Tertiary layer, rapidly eroded and redeposited in the lake, i.e. without enough time to reset the cosmogenic nuclides clock. These findings point towards a more complex depositional scenario, involving multiple surface exposures and burial sequences. The OSL dates are likely to represent age overestimates (hypothesis supported by catchment area dimension, overestimation of ${ }^{26} \mathrm{Al} /{ }^{10} \mathrm{Be}$ dating and no stratigraphic order of the OSL ages) but when considered in combination with the ${ }^{14} \mathrm{C}$ dating suggest that lacustrine sedimentation is likely to have taken place between 50 (lower limit of ${ }^{14} \mathrm{C}$ dating) and $350 \mathrm{ky}$ (upper limit of OSL dating).

Concerning pollen analysis (Fig. 7), the presence of Artemisia (up to 28.5\%), other steppic herbs, pioneer shrubs and the dominance of Pinus (up to $80 \%$ ) in the pollen assemblages are typical of glacial and lateglacial vegetation from the Upper to Middle Pleistocene periods in Western Provence (Triat-Laval, 1978). No Tertiary exotic taxa were observed in pollen slides. As the extinction of those taxa dates to the end of MIS 11 in Western Europe, the lacustrine infilling of Cassis is younger than MIS 11 ( $c a 400 \mathrm{ka}$ ) and dates from Middle to Upper Pleistocene.

The different elements of dating indicate an age (1) greater than 50 $\mathrm{ky}$, (2) less than $400 \mathrm{ky}$, and (3) from a cold period. Moreover, due to the sedimentary homogeneity with the absence of discontinuities, lacustrine sediments probably correspond to a unique continuous cold period. The intersection of these data can highlight the corresponding periods. MIS 6 ( 130 to $190 \mathrm{ky}$ ), MIS 8 ( 244 to $301 \mathrm{ky}$ ) and MIS 10 ( 334 to $364 \mathrm{ky}$ ) can match these criteria (Bassinot et al., 1994; Lisiecki and Raymo, 2005). Therefore, the sedimentary sequence of Cassis would represent a maximum period of deposition representing circa 30 to $60 \mathrm{ky}$.

Moreover, the analysis of calcareous nanofossils (Table 3 ) shows three main ages for the sediment source: Cenomanian ( 93-99 My), Aptian ( 112-125 My) and Valanginian-Hauterivian (130-140 My), with a dominant contribution of the Aptian. So the carbonate sedimentation is mostly the result of the erosion of Aptian marl coming from the eastern part of the catchment area. However, Aptian marls may not have supplied the sandy levels. The presence of Cenomanian fossils could confirm that sandy levels come from the erosion of the Cenomanian lithologies located to the east of the study area. The outcrop area of Aptian marls in the catchment area is about $\sim 4 \mathrm{~km}^{2}$ (Fig. 1) and the volume of the lacustrine sediment is about $4 \times 10^{6}$ $\mathrm{m}^{3}$. So one needs to erode on average about $1 \mathrm{~m}$ of Aptian marls to totally fill the karst depression (assuming total deposition of eroded material).

The maximum duration of sedimentation suggested here (30 to $60 \mathrm{ky}$ ) would provide minimum denudation rates ranging from 17 to $33 \mathrm{~m} / \mathrm{My}$. A comparable denudation rate of $37 \mathrm{~m} / \mathrm{My}$ was obtained on the nearby Cap Canaille cliff summit, which shares the same climate and slope as the catchment area (Braucher et al., 2011). Cap Canaille lithology being a hard conglomerate, one may expect a greater denudation rate in the Aptian marls, i.e. a sedimentation duration below $30 \mathrm{ky}$. This also agrees with studies in mountainous areas that showed that it is

Table 3

Distribution of calcareous nanofossils in the sedimentary records from the paleolake of Cassis (CAS, $\mathrm{n}=5$ ) and the underground river Bestouan (BST, $\mathrm{n}=3$ ).

\begin{tabular}{|c|c|c|c|c|c|}
\hline Sample & Index species & Known range & Inferred probable age & Associated species & Remarks \\
\hline CAS & $\begin{array}{l}\text { Braarudosphaera africana } \\
\text { Braarudosphaera bigelowii } \\
\text { Nannoconus truittii } \\
\text { N. quadriangulus } \\
\text { Litrhaphidites carniolensis } \\
\text { Eiffellithus striatus } \\
\text { Calcicalathina oblongata } \\
\text { Tubodiscus verenae }\end{array}$ & $\begin{array}{l}\text { Albian-Cenomanian } \\
\text { Cenomanian-present } \\
\text { Late Aptien-Campanian } \\
\text { Late Aptien-Albien } \\
\text { Late Berriasian-Maastrichtian } \\
\text { Late Valanginian-Late Hauterivian } \\
\text { Early Valanginian-Early } \\
\text { Barremian } \\
\text { Late Berriasian-Late Hauterivian }\end{array}$ & $\begin{array}{l}\text { Cenomanian } \\
\text { Aptian-Albian }\end{array}$ & $\begin{array}{l}\text { N. bonetii, } N \text {. bucherii, } N \text {. circularis, } N \text {. elongatus, } \\
\text { N. globulus, } N \text {. Kamptneri minor, M. obtusus, } \\
\text { B. constans, C. striatus, C. cuvillieri, D. Lehmani, } \\
\text { D. rotatorius, E. turriseiffelli, F. oblongus, } \\
\text { M. pemmatoidea, } R \text {. angustus, } R \text {. asper, S. crux, } \\
\text { various species of Watznaueria, various species } \\
\text { of Zeugrhabdotus }\end{array}$ & $\begin{array}{l}\text { Dominant contribution of } \\
\text { Aptian-Albian sediments }\end{array}$ \\
\hline $\begin{array}{l}\text { BST } 2 \\
\quad(P 1)\end{array}$ & $\begin{array}{l}\text { Kokia curvata } \\
\text { Eprolithus octopetalus } \\
\text { Biscutum magnum? }\end{array}$ & $\begin{array}{l}\text { Valanginian } \\
\text { Turonian } \\
\text { Santonian-Maastrichtian }\end{array}$ & $\begin{array}{l}\text { Valanginian } \\
\text { Turonian } \\
\text { ? Santonian-Maastrichtian }\end{array}$ & $\begin{array}{l}\text { L. carniolensis, B. constans, various species of } \\
\text { Watznaueria, various species of Zeugrhabdotus }\end{array}$ & $\begin{array}{l}\text { dominant contribution of } \\
\text { upper Cretaceous sediments }\end{array}$ \\
\hline $\begin{array}{l}\text { BST } 4 \\
(\text { P2) }\end{array}$ & Prediscosphaera ponticula & Albian-Maastricthian & Cenomanian-Maastricthian & $\begin{array}{l}\text { C. conicus, } R \text {. infinitus, various species of } \\
\text { Watznaueria }\end{array}$ & $\begin{array}{l}\text { Watznaueria species are quite } \\
\text { dominant }\end{array}$ \\
\hline $\begin{array}{l}\text { BST } 6 \\
\text { (P4) }\end{array}$ & - & - & $\begin{array}{l}\text { Early Cretaceous }+ \\
\text { ?Callovian-Oxfordian }\end{array}$ & $\begin{array}{l}\text { R. asper, S. crux, Z. embergeri, various species } \\
\text { of Watznaueria, various species of Zeugrhabdotus }\end{array}$ & $\begin{array}{l}\text { W. britannica, W. manivitiae, } \\
\text { W. ovata are quite dominant }\end{array}$ \\
\hline
\end{tabular}

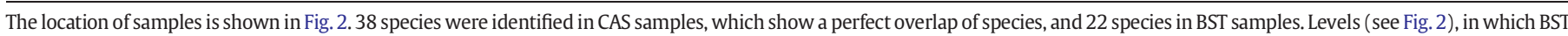
samples were collected, are shown within brackets. "?" indicates an uncertain identification. 
(a)

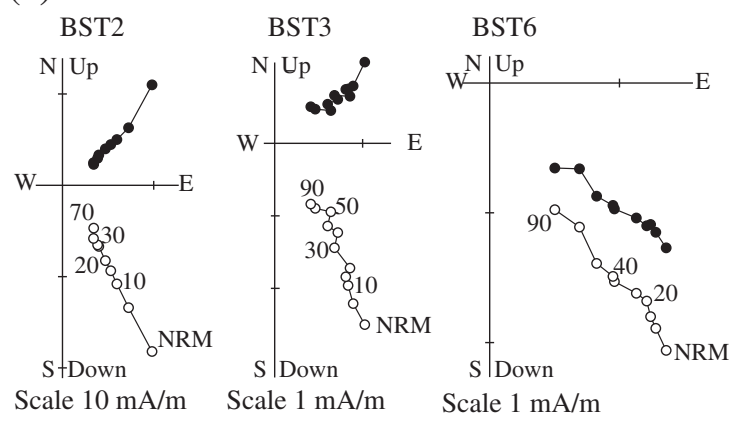

(b)

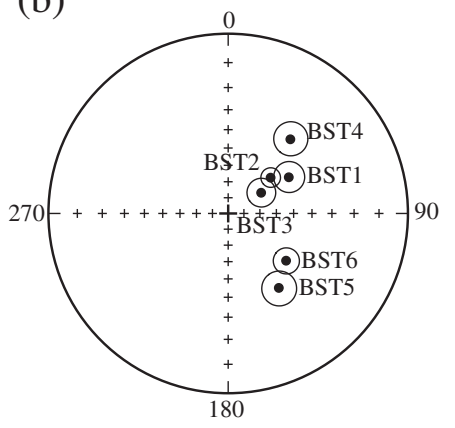

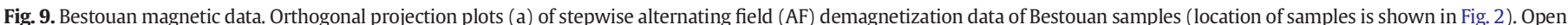

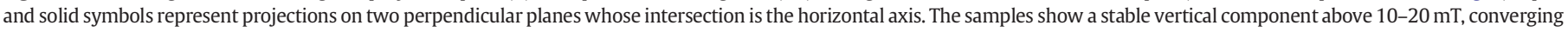

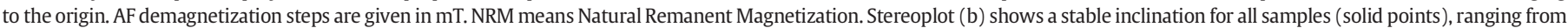

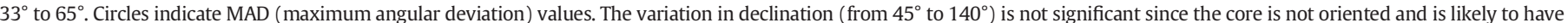
been twisted on the gravel layer.

possible to quickly fill a lake with a marl erosion rate of several mm/year (e.g. Rey, 2003).

Concerning the BST core, there is no way to obtain chronological constrains, apart from the consistent normal polarity of paleomagnetic signal (Fig. 9), supporting an age younger than $780 \mathrm{ka}$.

\subsection{Polje formation and link to Bestouan river}

The paleolake is located above karstified, fractured and faulted limestones (Fig. 8b (T0)). This context is very favourable for large cavity formation. The funnel shape of the subsurface karst as inferred from gravity data strongly suggests that the paleolake formation was controlled by two factors: the erosion of marls by surface flow and the formation of a karstic cavity in limestones, located at the centre of the depression (Fig. 8b (T1)). The karstic cavity was formed by the dissolution of limestones by water flow. The progression of ongoing limestone dissolution led to the collapse of the cavity or the creation of a vertical conduit, which created a karstic sinkhole establishing a connection between the surface and the Bestouan conduit (Figs. 1, 8b (T2)). Constant erosion of marls and drainage into the sinkhole with subsequent transport towards the now submerged outlet, combined with the high clay content of marls, caused a gradual clogging of the depression. Connection between surface and underground karstic network was thus interrupted (Fig. 8b (T3)). Once the cavity clogged, the depression created can operate as a lake and gradually be filled by sediments from the catchment (mostly Aptian marls) (Fig. 8b (T4)). The sequence of events described above is in agreement with other results obtained from studies of karstic lakes (e.g. Kindinger et al., 1999; Salvati and Sasowsky, 2002). Kindinger et al. (1999) detailed four progressive developmental stages of karstic lake formation: 1) the collapse of karst (active phase), 2) the filling of the cavity by sediments and the subsidence of the lake bottom (transitional phase), 3) the filling of the depression and 4) a phase of sinkhole development, associated with structural features (not observed in Cassis paleolake). Another formation hypothesis may be suggested by the fault located south of the polje. The fault brought into contact compact limestone and impermeable marls. This preferential drainage area could allow the establishment of a sinkhole, as commonly observed in karst area. However, the centre of the depression (Figs. 4,6) is about $100 \mathrm{~m}$ to the north of the fault and thus has no close relationship with the fault. If there had been a karstic sinkhole close to the fault, sediment thickness should be maximal, whilst geophysical measurements give a thickness of about $10 \mathrm{~m}$. Because of this configuration, it is unlikely that the fault is related to the formation of the polje. Even if the fault is not related to the formation of the polje, it could create a preferential drainage area that could have functioned as a minor outlet of the polje. The high homogeneity of sedimentary facies and the absence of unconformities and large deformation indicate that subsidence effects did not significantly affect the lacustrine sedimentation. The presence in the sedimentary record of a few microfaults (displacement less than a few centimetre) and a significant dip at the base could correspond to differential compaction. Moreover, from 45 to $50 \mathrm{~m}$ depth they are layers containing Aptian marls gravel from 10 to $20 \mathrm{~cm}$ thickness and abundant charcoals, whereas from 0 to $45 \mathrm{~m}$ depth, the core is poor in charcoal and devoid of gravels. The presence of marl pebbles and charcoals may be related to the instability of the slopes of the polje after its formation.

The proximity of this karstic structure, both in depth and location, with the ultimate point explored in the Bestouan submarine river is unlikely to be fortuitous and point towards a connection between the two. The hypothesis that the cavity collapse was recorded in the BST core through the succession of P3 and P2 levels cannot be grounded chronologically. The analysis of calcareous nanofossils found in BST core (Table 3) cannot give a precise age of the sediment eroded. Indeed, the three samples show a wide variety of nanofossils, covering the period from Upper Jurassic to Lower Cretaceous, characteristic of the area. The presence of fossils covering such a wide timescale can be explained by the extensive aquifer drained by the river (Blavoux et al., 2004) and/ or by remobilization of sediment. Clay mineralogy also points towards the fact that BST sediment is a mixture of different sources, with (in particular) chlorite that is not present in the paleolake sediments. However, it is possible to make assumptions about the relationship between the Bestouan river and the polje as well as its consequences on the sedimentation of Bestouan. Colour variation of the sediment BST can be related to a change of redox degrees during deposition. The grey colour of P2 layer indicates a reducing environment and is similar to sediment from the paleolake of Cassis, whilst ocher sediments (levels P1, P3 and P4) reflect an oxidizing environment. This change in the redox state of the sediment may be related to a decrease in oxygenation or a change in sediment source. P2 is characterised by a higher organic carbon content and carbonate content than P1, P3 and P4, indicative of rapid deposition of marl erosion products (Table 2). The layer of homogeneous sediments P4 could correspond to a sedimentary phase prior to the polje formation, with fine and homogeneous contributions coming from the erosion of karst aquifer drained by the Bestouan river. The layer rich in coarse elements $\mathrm{P} 3$ could be related to a collapse within the Bestouan drainage. For grey level P2, sedimentation in the Bestouan river could just precede lacustrine sedimentation. In this period, sediment coming from Aptian erosion, would go from the polje catchment area to the underground river through the karst sinkhole. The ocher sedimentation P1 could indicate clogging of the sinkhole by clay and the separation of the two systems (lake and underground river).

Cavalera (2007) studied a core BE1 coming from Bestouan river and taken at $100 \mathrm{~m}$ from the resurgence, i.e. about $50 \mathrm{~m}$ upstream core BST. $\mathrm{BE} 1$ sedimentation is composed of two layers A and B, which could 
correspond to levels P1 and P2, respectively. Given the absence of dating, it is not possible to be absolutely sure of the correlation between levels A-B and P1-P2. However, if a correlation between levels A-B and $\mathrm{P} 1-\mathrm{P} 2$ is assumed, the events described above are consistent with the sedimentation of BE1. In addition, the study of pollen indicates that lacustrine sedimentation took place during a cold period, i.e. a sea level lower than present (Antonioli et al., 2004), about 60 to $120 \mathrm{~m}$ bsl. Bestouan sedimentation of P3 layer is estimated to shortly predate lacustrine sedimentation, thus likely occurring also in a cold period. The Bestouan conduit is located today approximately between 10 and $30 \mathrm{bsl}$ and was thus emerged during lacustrine sedimentation. Karstic sedimentation occurs in flooded caves, implying that the karst conduit acted as a perched sump in the low permeability carbonate matrix of cretaceous limestones, fed by the polje outlet and further karst drainage.

\section{Conclusions}

Multi-method geophysical investigations allow the delineation of the shape of a polje filled by lacustrine sediments, in Cassis (SE France) in a coastal carbonate environment. A few metres of Holocene deposits, referred as an alluvial plain at about $90 \mathrm{~m}$ above sea level, hide a huge infilling in a karstic depression. The karstic features of the region are ubiquitous, such as the Calanques karstic landforms, or a large polje (Cuges) $12 \mathrm{~km}$ north of the studied area, but in the studied area of Cassis only submarine karstic springs were known. The combination of several dating methods, albeit of limited efficacy, and paleoenvironmental proxies indicates that the polje was filled during a glacial period (MIS 6, 8 or 10, i.e. in the $130-360$ ka range). The $3 \mathrm{~km}$-long karst conduit of Bestouan already existed, acting as an underground bypass for surface flow through a sinkhole before the filling of the polje. The Messinian Salinity Crisis is commonly taken into account to explain the development of karst at a great depth below the current sea level around the Mediterranean sea. However, Quaternary karstic evolution is highlighted in this paper and shows that karst hydrogeological functioning or geotechnical issues must account for the successive stages of karst development or infilling, hidden under coastal plains.

\section{Acknowledgements}

This research was funded by the ECCOREV federation and benefited from a PhD scholarship funded by the Conseil Regional PACA and FEDER fund, with the support of the Parc National des Calanques. We thank the INSU gmob (gravity mobile) facility for loaning the CG5 gravimeter. M. Arnold, G. Aumaître and K. Keddadouche are thanked for their valuable assistance during ${ }^{10} \mathrm{Be}$ and ${ }^{26} \mathrm{Al}$ measurements at ASTER. Speleo-divers from FFESSM and Cassis Rivière Mystérieuse associations are warmly thanked for sharing their exploration and topographic data. We also acknowledge the altruism of several private landowners who repeatedly let us work in their fields and vineyards, as well as the help of the Cassis municipality.

\section{References}

Aitken, M.J., 1985. Thermoluminescence Dating. Academic Press, Orlando, Florida.

Antonioli, F., Bard, E., Potter, E.-K., Silenzi, S., Improta, S., 2004. 215-ka history of sea-level oscillations from marine and continental layers in Argentarola Cave speleothems (Italy). Glob. Planet. Chang. 43, 57-78.

Arfib, B., Douchet, M., 2011. State of hydrogeological and cave-diving knowledge about the submarine rivers of Port Miou and Bestouan (Cassis, France). In: Bertrand, C., Carry, N., Mudry, J., Pronk, M., Zwahlen, F. (Eds.), Proceedings of the 9th Conference on Limestone Hydrogeology, 1-3 Sept. 2011, Besançon (France), pp. 301-306.

Arfib, B., Lamarque, T., 2012. Résultats préliminaires et premières interprétations du traçage KarstEAU du 08 février 2011 par injection de Sulforhodamine B à la perte de Mauregard (Ceyreste). Résultats positifs sur les sources sous-marines de la baie de Cassis: Bestouan et Port MiouAix-Marseille Université (14 pp.).

Arfib, B., Cavalera, T., Gilli, E., 2006. Influence of hydrodynamics on saline intrusion in coastal karstic aquifers. C. R. Geosci. 338, 757-767.
Arfib, B., de Marsily, G., Ganoulis, J., 2007. Locating the zone of saline intrusion in a coastal karst aquifer using springflow data. Ground Water 45, 28-35.

Audra, P., Palmer, A.N., 2013. The vertical dimension of karst: controls of vertical cave pattern. In: Shroder, John F. (Ed.), Treatise on Geomorphology, 6. Academic Press, San Diego, pp. 186-206.

Audra, P., Mocochain, L., Camus, H., Gilli, E., Clauzon, G., Bigot, J.-Y., 2004. The effect of the Messinian deep stage on karst development around the Mediterranean Sea. Examples from southern France. Geodin. Acta 17, 27-38.

Banerjee, D., Murray, A.S., Bøtter-Jensen, L., Lang, A., 2001. Equivalent dose estimation using a single aliquot of polymineral fine grains. Radiat. Meas. 33, 73-94.

Bassinot, F.C., Labeyrie, L.D., Vincent, E., Quidelleur, X., Shackleton, N.J., Lancelot, Y., 1994. The astronomical theory of climate and the age of the Brunhes-Matuyama magnetic reversal. Earth Planet. Sci. Lett. 126, 91-108.

Bièvre, G., Kniess, U., Jongmans, D., Pathier, E., Schwartz, S., van Westen, C.J., Villemin, T., Zumbo, V., 2011. Paleotopographic control of landslides in lacustrine deposits (Trièves plateau, French western Alps). Geomorphology 125, 214-224.

Biscaye, P.E., 1965. Mineralogy and sedimentation of recent deep-sea clays in the Atlantic Ocean and the adjacent seas and oceans. Geol. Soc. Am. Bull. 76, 803-832.

Blakely, R.J., 1996. Potential Theory in Gravity and Magnetic Applications. Cambridge University Press, Cambridge (464 pp.).

Blavoux, B., Gilli, E., Rousset, C., 2004. Watershed and origin of the salinity of the karstic submarine spring of Port-Miou. C. R. Geosci. 336, 523-533.

Bonvalot, S., Remy, D., Deplus, C., Diament, M., Gabalda, G., 2008. Insights on the March 1998 eruption at Piton de la Fournaise volcano (La Reunion) from microgravity monitoring. J. Geophys. Res. Solid Earth 113 (B5).

Bos, M.S., Scherneck, H.-G., d. http://froste.oso.chalmers.se/loading (consulted in December 2011).

Böse, M., Lüthgens, C., Lee, J.R., Rose, J., 2012. Quaternary glaciations of northern Europe Quat. Sci. Rev. 44, 1-25.

Bøtter-Jensen, L., 1997. Luminescence techniques: instrumentation and methods. Radiat. Meas. 27, 749-768.

Bøtter-Jensen, L., Bulur, E., Duller, G.A.T., Murray, A.S., 2000. Advances in luminescence instrument systems. Radiat. Meas. 32, 523-528.

Bown, P.R., 1998. Calcareous Nannoplankton Biostratigraphy. British Micropaleontological Press, London (320 pp.).

Bown, P.R., Young, J.R., 1998. Techniques. In: Bown, P.R. (Ed.), Calcareous Bannoplankton Biostratigraphy. British Micropaleontological Press, London, pp. 16-28.

Bradley, R.S., 1999. Paleoclimatology: reconstructing climates of the quaternary, 2nd edition. International Geophysics Serie, 64. San Diego Academic Press, San Diego (613 pp.).

Braucher, R., Bourlès, D.L., Brown, E.T., Colin, F., Muller, J.-P., Braun, J.-J., Delaune, M., Edou Minko, A., Lescouet, C., Raisbeck, G.M., Yiou, F., 2000. Application of in situ-produced cosmogenic ${ }^{10} \mathrm{Be}$ and ${ }^{26} \mathrm{Al}$ to the study of lateritic soil development in tropical forest: theory and examples from Cameroon and Gabon. Chem. Geol. 170, 95-111.

Braucher, R., Merchel, S., Borgomano, J., Bourlès, D.L., 2011. Production of cosmogenic radionuclides at great depth: a multi element approach. Earth Planet. Sci. Lett. 309, 1-9.

Butler, D.K., 1984. Microgravimeric and gravity gradient techniques for detection of subsurface cavities. Geophysics 49, 1084-1096.

Canora, F., Fidelibus, D., Spilotro, G., 2012. Coastal and inland karst morphologies driven by sea level stands: a GIS based method for their evaluation. Earth Surf. Process. Landf. 37, 1376-1386.

Cara, F., Di Giulio, G., Milana, G., Bordoni, P., Haines, J., Rovelli, A., 2010. On the stability and reproducibility of the horizontal-to-vertical spectral ratios on ambient noise: Case Study of Cavola, Northern Italy. Bull. Seismol. Soc. Am. 100, 1263-1275.

Cavalera, T., 2007. . (Ph.D. Thesis) Etude du fonctionnement et du basin d'alimentation de la source sous-marine de Port-Miou (Cassis, Bouches-du-Rhône). Approche multicritèreAix-Marsielle Université, France (403 pp.).

Chalikakis, K., Plagnes, V., Guerin, R., Valois, R., Bosch, F.P., 2011. Contribution of geophysical methods to karst-system exploration: an overview. Hydrogeol. J. 19, 1169-1180.

de Waele, J., Plan, L., Audra, P., 2009. Recent developments in surface and subsurface karst geomorphology: an introduction. Geomorphology 106, 1-8.

Debrand-Passard, S., Courbouleix, S., Lienhart, M.-J., 1984. Synthèse géologique du Sud-Est de la France. Mem. BRGM 125-126 (615 pp.).

Delannoy, J.J., Gauchon, C., Hobléa, F., Jaillet, S., Maire, R., Perrette, Y., Perroux, A.-S. Ployon, E., Vanara, N., 2009. Karst: from palaeogeographic archives to environmental indicators. Géomorphologie 2, 83-94.

Delgado, J., López Casado, C., Estévez, A., Giner, J., Cuenca, A., Molina, S., 2000. Mapping soft soils in the Segura River valley (SE Spain): a case study of microtremors as an exploration tool. J. Appl. Geophys. 45, 19-32.

Demory, F., Nowaczyk, N.R., Witt, A., Oberhänsli, H., 2005. High-resolution magnetostratigraphy of late quaternary sediments from Lake Baikal, Siberia: timing of intracontinental paleoclimatic responses. Glob. Planet. Chang. 4, 167-186.

Demory, F., Conesa, G., Oudet, J., Mansouri, H., Münch, P., Borgomano, J., Thouveny, N. Lamarche, J., Gisquet, F., Marié, L., 2011. Magnetostratigraphy and paleoenvironments in shallow-water carbonates: the Oligocene-Miocene sediments of the northern margin of the Liguro-Provençal basin (West Marseille, southeastern France). Bull. Soc. Geol. Fr. 182, 35-55.

di Giulio, G., Cornou, C., Ohrnberger, M., Wathelet, M., Rovellii, A., 2006. Deriving wavefield characteristics and shear-velocity profiles from two-dimensional smallaperture arrays analysis of ambient vibrations in a small-size alluvial basin, Colfiorito, Italy. Bull. Seismol. Soc. Am. 96, 1915-1933.

Donahue, D.J., 1995. Radiocarbon analysis by accelerator mass spectrometry. Int. J. Mass Spectrom. Ion Process. 143, 235-245.

Dvorkin, J., Walls, J., Mavko, G., 2001. Rock physics of marl. SEG Technical Program Expanded Abstracts 2001, pp. 1784-1787.

Fleury, P., Bakalowicz, M., de Marsily, G., 2007. Submarine springs and coastal karst aquifers: a review. J. Hydrol. 339, 79-92. 
Ford, D.C., Williams, P.W., 2007. Karst Hydrogeology and Geomorphology. John Wiley \& Sons Ltd., Chichester, United Kingdom (576 pp.).

Fournier, F., Leonide, P., Biscarrat, K., Gallois, A., Borgomano, J., Foubert, A., 2011. Elastic properties of microporous cemented grainstones. Geophysics 76, 1-17.

GM-SYS, 2001. Geophysical Processing and Analysis module of Geosoft, Inc.

Griffiths, D.H., Turnbull, J., Olayinka, A.I., 1990. Two-dimensional resistivity mapping with a computer-controlled array. First Break 8, 121-129.

Guéguen, D., Cornou, C., Garambois, S., Banton, J., 2007. On the limitation of the H/V spectral ratio using seismic noise as an exploration tool: application to the Grenoble Valley (France), a small apex ratio basin. Pure Appl. Geophys. 164, 115-134.

Jacob, T., Bayer, R., Chery, J., Le Moigne, N., 2010. Time-lapse microgravity surveys revea water storage heterogeneity of a karst aquifer. J. Geophys. Res. Solid Earth 115 (B6). http://dx.doi.org/10.1029/2009JB006616.

Kindinger, J.L., Davis, J.B., Flocks, J.G., 1999. Geology and evolution of lakes in north-central Florida. Environ. Geol. 38, 301-321.

Kirschvink, J.L., 1980. The least-square line and plane and the analysis of paleomagnetic data. Geophys. J. Int. 62, 699-718.

Konno, K., Ohmachi, T., 1998. Ground-motion characteristics estimated from spectral ratio between horizontal and vertical components of microtremor. Bull. Seismol. Soc. Am. $88,228-241$.

Krijsman, W., Hilgen, F.J., Raffi, I., Sierro, F.J., Wilson, D.S., 1999. Chronology, causes and progression of the Messinian salinity crisis. Nature 400, 652-655.

Lamarche, J., Lavenu, A.P.C., Gauthier, B.D.M., Guglielmi, Y., Jayet, O., 2012. Relationships between fracture patterns, geodynamics and mechanical stratigraphy in Carbonates (South-East Basin, France). Tectonophysics 581, 231-245.

Lamb, H.F., Bates, C.R., Coombes, P.V., Marshall, M.H., Umer, M., Davies, S.J., Dejen, E., 2007. Late Pleistocene dessication of Lake Tana, source of the Blue Nile. Quat. Sci. Rev. 26 287-299.

Lisiecki, L.E., Raymo, M.E., 2005. A Pliocene-Pleistocene stack of 57 globally distributed benthic D180 records. Paleoceanography 20, PA1003. http://dx.doi.org/10.1029/ 2004PA001071.

Loke, M.H., Barker, R.D., 1995. Least-squares deconvolution of apparent resistivity pseudosections. Geophysics 60, 1682-1690.

Lyard, F., Lefevre, F., Letellier, T., Fracis, O., 2006. Modelling the global ocean tides: modern insights from FES2004. Ocean Dyn. 56, 394-415.

Margiotta, S., Negri, S., Parise, M., Valloni, R., 2012. Mapping the susceptibility to sinkholes in coastal areas, based on stratigraphy, geomorphology and geophysics. Nat. Hazards 62, 657-676.

Marriner, N., Morhange, C., Borschneck, D., Flaux, C., 2011. Holocene sedimentary sources in southern Lebanon, Eastern Mediterranean. Quat. Int. 266, 105-116.

Martín, A., Anquela, A.B., Padín, J., Berné, J.L., 2011. On standard reductions to relative gravity measurements. A case study through the establishment of the new local gravity net in the province of Valencia (Spain). Surv. Rev. 43, 16-29.

Mejdahl, V., 1985. Thermoluminescence dating of partially bleached sediments. Nucl. Tracks Radiat. Meas. 10, 711-715.

Méric, O., Garambois, S., Malet, J.-P., Cadet, H., Gueguen, P., Jongmans, D., 2007. Seismic noise-based methods for soft-rock landslide characterization. Bull. Soc. Geol. Fr. $178,137-148$

Merlet, S., Kopaev, A., Diament, M., Geneves, G., Landragin, A., Pereira Dos Santos, F., 2008. Micro-gravity investigations for the LNE watt balance project. Metrologia 45, 265-274.

Metwaly, M., AlFouzan, F., 2013. Application of 2-D geoelectrical resistivity tomography for subsurface cavity detection in the eastern part of Saudi Arabia. Geosci. Front 4, 469-476.

Mocochain, L., Clauzon, G., Bigot, J.-Y., Brunet, P., 2006. Geodynamic evolution of the periMediterranean karst during the Messinian and the Pliocene: evidence from the Ardèche and Rhône Valley systems canyons, Southern France. Sediment. Geol. 188-189, 219-233.

Mocochain, L., Audra, P., Clauzon, G., Bellier, O., Bigot, J.Y., Parize, O., Monteil, P., 2009. The effect of river dynamics induced by the Messinian Salinity Crisis on karst landscape and caves: example of the Lower Ardèche river (mid Rhône valley). Geomorphology 106, 46-61.

Molliex, S., Bellier, O., Terrier, M., Lamarche, J., Martelet, G., Espurt, N., 2011. Tectonic and sedimentary inheritance on the structural framework of Provence (SE France): importance of the Salon-Cavaillon fault. Tectonophysics 501, 1-16.

Moore, D.M., Reynolds Jr., K., 1989. X-ray Diffraction and Identification and Analysis of Clay Minerals. Oxford University Press, Oxford (322 pp.).

Murray, A.S., Wintle, A.G., 2000. Luminescence dating of quartz using an improved singlealiquot regenerative-dose protocol. Radiat. Meas. 32, 57-73.

Nakagawa, T., Brugiapaglia, E., Digerfeldt, G., Reille, M., de Beaulieu, J.L., Yasuda, Y., 1998. Dense-media separation as a more efficient pollen extraction method for use with or ganic sediment samples: comparison with the conventional method. Boreas 27, 15-24.
Nakamura, Y., 1989. A methods for dynamic characteristics estimation of subsurface using microtremor on the ground surface. Quarterly Report of the Railway Technology Research Institute, 30, pp. 25-33.

Nordiana, M.M., Saad, R., Nawawi, M.N.M., Azwin, I.N., Tonnizam Mohamad, E., 2013. Case study: shallow subsurface geology mapping using 2-D resistivity imaging with EHR technique. APCBEE Procedia 134-140.

Pueyo-Anchuela, Ó., Casas-Sainz, A.M., Soriano, M.A., Pocoví-Juan, A., 2011. Geophysical techniques applied to urban planning in complex near surface environments. Examples of Zaragoza, NE Spain. Phys. Chem. Earth 36, 1211-1227.

Ramadass, G., Ramaprasada Rao, I.B., Himabindu, D., 2006. Crustal configuration of the Dharwar craton, India, based on joint modeling of regional gravity and magnetic data. J. Asian Earth Sci. 26, 437-448.

Rey, F., 2003. Influence of vegetation distribution on sediment yield in forested marly gullies. Catena 50, 549-562.

Romey, C., 2013. Histoire des paysages et de l'occupation humaine du Massif des Calanques depuis 300000 ans. (PhD thesis) Aix-Marseille University, France (298 pp.).

Rosenblad, B.L., Goetz, R., 2010. Study of the H/V spectral ratio method for determining average shear wave velocities in the Mississippi embayment. Eng. Geol. 112, 13-20.

Rouchy, J.M., Caruso, A., 2006. The Messinian salinity crisis in the Mediterranean basin: a reassessment of the data and an integrated scenario. Sed. Geol. 188-189, 35-67.

Rucker, D.F., Noonan, G.E., Greenwood, W.J., 2011. Electrical resistivity in support of geological mapping along the Panama Canal. Eng. Geol. 117, 121-133.

Salvati, R., Sasowsky, I.D., 2002. Development of collapse sinkholes in areas of groundwater discharge. J. Hydrol. 264, 1-11.

Samouëlian, A., Cousin, I., Tabbagh, A., Bruand, A., Richard, G., 2005. Electrical resistivity survey in soil sciences: a review. Soil Tillage Res. 83, 173-193.

SESAME European research project WP12, 2004. Guidelines for the implementation of the $\mathrm{H} / \mathrm{V}$ spectral ratio technique on ambient vibrations - measurements, processing and interpretation. Project No. EVG1-CT- 2000-00026 SESAME, Deliverable D23.12, March 2006 (http://sesame-fp5.obs.ujf-grenoble.fr).

Siart, C., Hecht, S., Holzhauer, I., Altherr, R., Meyer, H.P., Schukraft, G., Eitel, B., Bubenzer, O., Panagiotopoulos, D., 2010. Karst depressions as geoarchaeological archives: the palaeoenvironmental reconstruction of Zominthos (Central Crete), based on geophysical prospection, sedimentological investigations and GIS. Quat. Int. 216, 75-92.

Štěpančíková, P., Dohnal, J., Pánek, T., Łój, M., Smolková, V., Šilhán, K., 2011. The application of electrical resistivity tomography and gravimetric survey as useful tools in an active tectonics study of the Sudetic Marginal Fault (Bohemian Massif, central Europe). J. Appl. Geophys. 74, 69-80.

Styles, P., McGrath, R., Thomas, E., Cassidy, N.J., 2005. The use of microgravimetre for cavity characterization in karstic terrains. Q. J. Eng. Geol. Hydrogeol. 38, 155-169.

Tassy, A., Arfib, B., Gilli, E., 2010. Access to coastal karst water resources through a salinity study during an exceptional high-water event: the case of Port-Miou (Cassis, SE France). In: Carrasco, F., Duran Valsero, J.J.D., LaMoreaux, J.W. (Eds.), IVe Symposium on Karst, Malaga (Spain). Advances in Research in Karst Media. Environmental Earth Sciences, pp. 49-55

Triat-Laval, H., 1978. Contribution pollenanalytique à l'histoire tardi- et postglcaire de la végétation de la basse-vallée du Rhône. (PhD thesis) Aix-Marseille III University, France (343 pp.).

Tudryn, A. Giannesini, P.-J., Guichard, F, Badaut-Trauth, D. Tucholka, P., Boomer, I, 2014. The role of iron minerals in laminae formation in Late Pleistocene sediments of the Caspian Sea. Quat. Int. http://dx.doi.org/10.1016/j.quaint.2013.04.024 (in press).

Vadillo, I., Benavente, J., Neukum, C., Grützner, C., Carrasco, F., Azzam, R., Liñán, C., Reicherter, K., 2012. Surface geophysics and borehole inspection as an aid to characterizing karst voids and vadose ventilation patterns (Nerja research site, S. Spain). J. Appl. Geophys. 82, 153-162.

van Camp, M., Vauterin, P., 2005. TSoft: graphical and interactive software for the analysis of time series and Earth tides. Comput. Geosci. 31, 631-640.

van Geen, A., Zheng, Y., Bernhard, J.M., Cannariato, K.G., Carriquiry, J.D., Dean, W.E., Eakins, B.W., Ortiz, J.D., Pike, J., 2003. On the preservation of laminated sediments along the Western margin of North America. Paleoceanography 18, 1098. http://dx.doi.org/ 10.1029/2003PA000911.

van Hengstum, P.J., Scott, D.B., Gröcke, D.R., Charette, M.A., 2011. Sea level controls sedimentation and environments in coastal caves and sinkholes. Mar. Geol. 286, 35-50.

Wathelet, M., Jongmans, D., Ohrnberger, M., Bonnefoy-Claudet, S., 2008. Array performances for ambient vibrations on a shallow structure and consequences over $V_{s}$ inversion. J. Seismol. 12, 1-19.

Wintle, A.G., Murray, A.S., 2006. A review of quartz optically stimulated luminescence characteristics and their relevance in single-aliquot regeneration dating protocols. Radiat. Meas. 41, 369-391. 